\title{
Crystallographic Insights into the Behavior of Highly Acidic Metal Cations in Ionic Liquids from Reactions of Titanium Tetrachloride with [1-Butyl-3-Methylimidazolium][X] Ionic Liquids $(X=$ Chloride, Bromide, Tetrafluoroborate)
}

\author{
Manish Kumar Mishra, ${ }^{a}$ Steven P. Kelley, ${ }^{\mathrm{a},}$ Meghna Dilip,,${ }^{\mathrm{a} \dagger}$ Thomas P. Vaid, ${ }^{\mathrm{a},}$ David B.

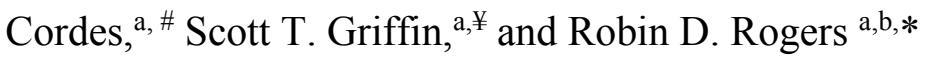

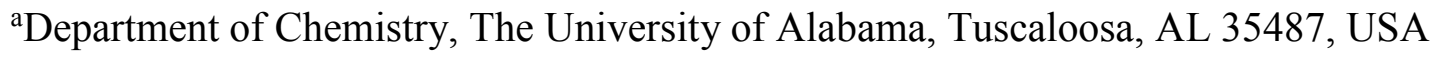 \\ b525 Solutions, Inc., P.O. Box 2206, Tuscaloosa, AL 35403, USA
}

\begin{abstract}
Highly charged metal ions are difficult to investigate in weakly coordinating ionic liquids (ILs) because of the insolubility of their solid forms, but the molecular liquid $\mathrm{TiCl}_{4}$ offers a way to react tetravalent metal ions in an IL. Reactions of $\mathrm{TiCl}_{4}$ with 1-butyl-3-methylimidazolium $\left(\left[\mathrm{C}_{4} \mathrm{mim}\right]^{+}\right)$-based ILs containing chloride or bromide lead to mixtures of highly metastable amorphous solids and small amounts of crystalline chlorotitanate salts including $\left[\mathrm{C}_{4} \mathrm{mim}\right]_{2}\left[\mathrm{TiCl}_{6}\right]$ and two polymorphs of $\left[\mathrm{C}_{4} \mathrm{mim}\right]_{2}\left[\mathrm{Ti}_{2} \mathrm{Cl}_{10}\right]$ in a manner not well correlated with stoichiometry or anion identity. The reaction of $\mathrm{TiCl}_{4}$ with $\left[\mathrm{C}_{4} \mathrm{mim}\right]\left[\mathrm{BF}_{4}\right]$ yields crystals of the mixed fluoro-chloro complex $\left[\mathrm{C}_{4} \mathrm{mim}\right]_{2}\left[\mathrm{Ti}_{4} \mathrm{~F}_{6} \mathrm{Cl}_{12}\right]$, indicating spontaneous reaction of the IL ions to generate HF in situ. These unusual behaviors are explained in terms of the exceptionally high acidity of $\mathrm{Ti}^{4+}$ and the unusual behavior of $\mathrm{TiCl}_{4}$ among metal halides as a nonpolar molecular compound.
\end{abstract}

\section{Introduction}

There is a practically unlimited array of near-ambient temperature ionic liquids (ILs) that can be made by combining different pairs ${ }^{1}$ or groups ${ }^{2}$ of ions. This great diversity contrasts with molecular compounds, where the structure of the molecule cannot be changed without affecting both its chemical and physical properties, and has led to ILs being viewed as "designer" solvents. One of the best examples of the tunability of ILs are those which include ionic coordination complexes such as halometallates, ${ }^{3}$ where a wide range of speciation-diverse systems can be made by simply combining an organic salt and a metal salt at different ratios. Adding neutral ligands ${ }^{4,5}$ or combining different metal ions ${ }^{6}$ generates even more chemical diversity from ILs based on ionic coordination complexes.

Halometallate ILs were one of the first IL systems to be studied in detail, beginning with alkylpyridinium chloroaluminate melts in $1979,{ }^{7}$ but it is likely that the incredible structural variability of these systems will never be fully explored. There remain certain areas of halometallate IL structural chemistry that are comparatively under-investigated, particularly metal ions with high oxidation states. This is especially clear if one looks at the published crystal structures of 1,3-dialkylimidazoium chlorometallates, an especially well-investigated subset of halometallate ILs. Many such structures are reported for 
divalent metal ions including $\mathrm{Cr},{ }^{8} \mathrm{Cu},{ }^{9,10,11,12} \mathrm{Co},{ }^{11,13,14} \mathrm{Fe},{ }^{11,15} \mathrm{Ge},{ }^{16} \mathrm{Hg},{ }^{17} \mathrm{Mn},{ }^{11} \mathrm{Ni},{ }^{11,13}$ $\mathrm{Pb},{ }^{18} \mathrm{Pd}^{9,19,20,21}, \mathrm{Pt},{ }^{11} \mathrm{Sn},{ }^{11,22}$ and $\mathrm{Zn} .{ }^{11,23} \mathrm{In}$ addition to the well-studied [ $\left.\mathrm{AlCl}_{4}\right]^{-}$ systems, ${ }^{24}$ crystal structures are known for chlorometallates of trivalent $\mathrm{Au},{ }^{25,26} \mathrm{Bi}^{27}$ $\mathrm{Ce},{ }^{28,29} \mathrm{Dy},{ }^{30} \mathrm{Er},{ }^{30,31} \mathrm{Eu},{ }^{30,32} \mathrm{Fe},{ }^{33,34,35} \mathrm{Gd},{ }^{32} \mathrm{La},{ }^{36,37} \mathrm{Nd},{ }^{32} \mathrm{Pr},{ }^{32} \mathrm{Sb}^{38} \mathrm{Sc}^{29} \mathrm{Sm}^{32}, \mathrm{Y},{ }^{29}$ and $\mathrm{Yb} .{ }^{30}$ However, for tetravalent metal ions, the list is restricted to just $\mathrm{Ge},{ }^{16} \mathrm{Ir},{ }^{25} \mathrm{Pt},{ }^{25} \mathrm{Sn},{ }^{22}$ $\mathrm{Ti}^{39,40,41} \mathrm{U},{ }^{42} \mathrm{~V},{ }^{43}$ and $\mathrm{Zr},{ }^{11,39,44,45,46}$ for pentavalent ions only $\mathrm{Np},{ }^{47}$ and $\mathrm{Nb},{ }^{48,49}$ and for hexavalent ions only $\mathrm{U}^{50}$ and Mo. ${ }^{51,52}$ This may reflect how the weakly coordinating ions found in many commonly used ILs cannot dissolve salts of highly charged ions. However, these same ILs are also the most interesting for exploring new, non-aqueous catalytic chemistry of highly charged metal ions because their high Lewis acidity will not be weakened by strong interactions with the solvent.

Titanium tetrachloride $\left(\mathrm{TiCl}_{4}\right)$ is especially interesting in this regard, as it is an extremely strong Lewis acid and a nonpolar liquid whose interactions have already been studied with other liquids including nonpolar aromatic solvents, ${ }^{53}$ polar organic solvents, ${ }^{54}$ and supercritical $\mathrm{CO}_{2} .{ }^{55}$ Its interactions with inorganic salts are also well investigated ${ }^{56}$ and of great importance in the preparation of $\mathrm{TiCl}_{4}$, which is itself the most important industrial precursor for $\mathrm{Ti}$ metal and pigment-quality $\mathrm{TiO}_{2}{ }^{57}$ Being a liquid itself, there is potentially little limit to the range of ILs with which $\mathrm{TiCl}_{4}$ could be reacted to exploit the extreme acidity of the $\mathrm{Ti}^{4+}$ cation in unexplored solvent environments.

A number of investigations on the combination of $\mathrm{TiCl}_{4}$ with ILs have been published, and they present an interesting, apparently contradictory body of observations. One of the earliest reports, from 1990, observed that the reaction of $\mathrm{TiCl}_{4}$ and 1-ethyl-3methylimidazolium $\left(\left[\mathrm{C}_{2} \mathrm{mim}\right]^{+}\right)$chloride did not give a liquid salt, in contrast to $\mathrm{AlCl}_{3}$ and many other high valent metals. In 2009, it was reported that $\mathrm{TiCl}_{4}$ could be reacted directly with 1-butyl-3-methylimidazolium $\left(\left[\mathrm{C}_{4} \mathrm{mim}\right]^{+}\right)$chloride at $100-120{ }^{\circ} \mathrm{C}$ to give room-temperature ILs at 1:1 and 1:2 ratios of [ $\left.\mathrm{C}_{4} \mathrm{mim}\right] \mathrm{Cl}$ to $\mathrm{TiCl}_{4}{ }^{58} \mathrm{Raman}$ spectroscopic studies of these liquids indicated that $\mathrm{Ti}^{4+}$ in these ILs was in equilibrium between the species $\left[\mathrm{TiCl}_{6}\right]^{2-}$ and $\left[\mathrm{Ti}_{2} \mathrm{Cl}_{9}\right]^{-}$. However, the reaction of $\mathrm{TiCl}_{4}$ with $\left[\mathrm{C}_{4} \mathrm{mim}\right]\left[\mathrm{AlCl}_{4}\right]$ was later reported to give crystalline $\left[\mathrm{C}_{4} \mathrm{mim}\right]_{2}\left[\mathrm{Ti}_{2} \mathrm{Cl}_{10}\right],{ }^{40}$ while the reaction of $\left[\mathrm{C}_{4} \mathrm{mim}\right] \mathrm{Cl}$ with $\mathrm{TiCl}_{4}$ in dichloromethane yielded $\left[\mathrm{C}_{4} \mathrm{mim}\right]_{2}\left[\mathrm{TiCl}_{6}\right]$ as a crystalline compound. ${ }^{41}$ Thus the physical state and even speciation in which $\left[\mathrm{C}_{4} \mathrm{mim}\right]^{+}$salts of chlorotitanates are isolated appears to be especially sensitive, not only to the ratio of $\mathrm{Ti}^{4+}$ to halide but also to the method of preparation.

In this study, we sought to expand upon these investigations of $\mathrm{TiCl}_{4}$ speciation, which were limited to $\mathrm{Cl}^{-}$containing media, by exploring and comparing the reactions of $\mathrm{TiCl}_{4}$ with $\left.\left[\mathrm{C}_{4} \mathrm{mim}\right]^{+}\right)$-based ILs with various anions $\left(\mathrm{Cl}^{-}, \mathrm{Br}^{-}\right.$, and $\left.\left[\mathrm{BF}_{4}\right]^{-}\right)$. Surprisingly, these systems yielded crystalline $\mathrm{Ti}^{4+}$ complexes only as minor products, even when the bulk stoichiometries exactly matched that of the crystalline compound. Observations from these reactions and structural characterization of the isolated crystals give insights into the unusual crystallization mechanism, unexpected crystal polymorphism, and participation of the $\left[\mathrm{C}_{4} \mathrm{mim}\right]^{+}$cation in the formation of $\left[\mathrm{C}_{4} \mathrm{mim}\right]^{+}$chlorotitanates.

\section{Experimental}

\subsection{Materials Used}


1-chlorobutane, 1-methylimidazole, sodium tetrafluoroborate $\left(\mathrm{NaBF}_{4}\right)$, anhydrous dichloromethane $\left(\mathrm{CH}_{2} \mathrm{Cl}_{2}\right)$, and silver nitrate $\left(\mathrm{AgNO}_{3}\right)$ were purchased from SigmaAldrich (St. Louis, MO, USA). $\mathrm{TiCl}_{4}$ was used as obtained from Fluka (Seelze, Germany).

1-Butyl-3-methylimidazolium chloride $\left(\left[\mathrm{C}_{4} \mathrm{mim}\right] \mathrm{Cl}\right)$ was synthesized by reacting $5 \%$ molar excess of 1-chlorobutane with 1-methylimidazole under reflux for one week, until no measurable amount of 1-methylimidazole was detected using ${ }^{1} \mathrm{H}-\mathrm{NMR} .{ }^{59}$ To remove any excess water and unreacted 1-chlorobutane, the product was dried first on a rotary evaporator followed by a high vacuum line for at least $12 \mathrm{~h}$. 1-Butyl-3methylimidazolium bromide $\left(\left[\mathrm{C}_{4} \mathrm{mim}\right] \mathrm{Br}\right)$ was synthesized using the same procedure as $\left[\mathrm{C}_{4} \mathrm{mim}\right] \mathrm{Cl}$, but with an excess of 1-bromobutane in place of 1-chlorobutane.

For the synthesis of 1-butyl-3-methylimidazolium tetrafluoroborate $\left(\left[\mathrm{C}_{4} \mathrm{mim}\right]\left[\mathrm{BF}_{4}\right]\right)$, $\left[\mathrm{C}_{4} \mathrm{mim}\right] \mathrm{Cl}(30.00 \mathrm{~g}, 172 \mathrm{mmol})$ was reacted with $\mathrm{NaBF}_{4}(20.00 \mathrm{~g}, 182 \mathrm{mmol})$ in water with stirring. ${ }^{59}$ The product, $\left[\mathrm{C}_{4} \mathrm{mim}\right]\left[\mathrm{BF}_{4}\right]$, was extracted into $\mathrm{CH}_{2} \mathrm{Cl}_{2}$ through repeated extractions until the organic phase containing the IL showed no detectable halide contamination using an aqueous $\mathrm{AgNO}_{3}$ solution. Thereafter the $\mathrm{CH}_{2} \mathrm{Cl}_{2}$ phase was separated and dried first on the rotary evaporator followed by high vacuum for at least 12 h. The pure $\left[\mathrm{C}_{4} \mathrm{mim}\right]\left[\mathrm{BF}_{4}\right]$ is a colorless to pale yellow, viscous liquid at room temperature.

All samples used had 98\% minimum purity, as determined by NMR in an appropriate solvent. Water contents were measured using volumetric Karl-Fisher titration (EM Star, Lawrence, KS) and determined to be $<1 \%$.

\subsection{Reactions of $\mathrm{TiCl}_{4}$ with ILs}

CAUTION: $\mathrm{TiCl}_{4}$ is an extremely corrosive and pyrophoric material, thus should be handled with suitable Personal Protective Equipment (PPE). Also, the reactions reported herein are extremely exothermic.

The ILs, 1-butyl-3-methylimidazolium chloride (solid), bromide (solid), or tetrafluoroborate (liquid) were dried overnight under high vacuum, and were purged with $\mathrm{N}_{2}$ for $1 \mathrm{~h}$ before being melted at $70{ }^{\circ} \mathrm{C}$. All reactions were carried out in a $\mathrm{N}_{2}$-filled drybox. $\mathrm{TiCl}_{4}$ was transferred using a syringe under $\mathrm{N}_{2}$. For 1:1 reactions, the ILs were mixed with $\mathrm{TiCl}_{4}$ in 1:1 stochiometric ratios by adding 0.01 mol of molten IL with 0.01 mol (ca. $1 \mathrm{~mL}$ ) of $\mathrm{TiCl}_{4}$. For 2:1 reactions, the ILs were mixed with $\mathrm{TiCl}_{4}$ in $2: 1$ stochiometric ratios by adding $0.02 \mathrm{~mol}$ of molten IL to $0.01 \mathrm{~mol}$ (ca. $1 \mathrm{~mL}$ ) of $\mathrm{TiCl}_{4}$. For $1: 3$ and $3: 1, \mathrm{IL} \mathrm{TiCl}_{4}$ conditions, $0.03 \mathrm{~mol}$ of the appropriate reactant were used. All above mentioned stoichiometric and non-stoichiometric reactions were conducted by adding the IL to $\mathrm{TiCl}_{4}$ and also in the reverse order, i.e., adding $\mathrm{TiCl}_{4}$ to the IL. Suitable crystals for SCXRD formed upon cooling to room temperature for the reactions with $\left[\mathrm{C}_{4} \mathrm{mim}\right] \mathrm{Cl}$ and $\left[\mathrm{C}_{4} \mathrm{mim}\right] \mathrm{Br}$. Crystals for the reaction with $\left[\mathrm{C}_{4} \mathrm{mim}\right]\left[\mathrm{BF}_{4}\right]$ were obtained by further cooling to $0{ }^{\circ} \mathrm{C}$ in a refrigerator. All crystalline products were extremely hygroscopic, but could be isolated for X-ray diffraction studies using heavy hydrocarbon oil (Paratone-N, Hampton Chemicals, CA).

Grinding experiments were also attempted at room temperature using hand grinding under inert atmosphere. In general, $\mathrm{TiCl}_{4}(0.25 \mathrm{mmol})$ and each IL $(0.25 \mathrm{mmol}$ 
$\left[\mathrm{C}_{4} \mathrm{mim}\right] \mathrm{Cl},\left[\mathrm{C}_{4} \mathrm{mim}\right] \mathrm{Br}$, or $\left.\left[\mathrm{C}_{4} \mathrm{mim}\right]\left[\mathrm{BF}_{4}\right]\right)$ in $1: 1$ ratio were ground in an agate mortar with a pestle for 5-10 min each at room temperature under inert atmosphere leading to the formation of solids or liquids.

\subsection{X-ray Diffraction}

Single crystal X-ray diffraction (SCXRD) data were collected on a Bruker CCD area detector-equipped diffractometer (Madison, WI) with graphite-monochromated Mo-K $\alpha$ radiation $(\lambda=0.71073 \AA)$. The crystals were cooled to $-100{ }^{\circ} \mathrm{C}$ under a cold stream of nitrogen using an LT-2 cryostat (Bruker AXS). Absorption corrections were performed using SADABS. ${ }^{60}$ Structure solutions were carried out by direct methods using SHELXTL, ${ }^{61}$ and the structures were refined using full-matrix least-squares on $F^{2}$ (SHELXL 2014). ${ }^{62}$ Non-hydrogen atoms were refined anisotropically, and hydrogen atoms were refined using a riding $\left(\mathrm{CH}, \mathrm{CH}_{2}\right)$ or riding-rotating $\left(\mathrm{CH}_{3}\right)$ model. Some of the butyl chains in all the structures were found to be disordered. Additional partially occupied atoms were located, and all atoms involved in the disorder were refined anisotropically. Similarity restraints were required for modelling the disordered butyl chains in $\left[\mathrm{C}_{4} \mathrm{mim}\right]_{2}\left[\mathrm{TiCl}_{6}\right]$. All three structures were affected by twinning, and were refined with incorporation of the relevant twin law.

The crystals of $\left[\mathrm{C}_{4} \mathrm{mim}\right]_{2}\left[\mathrm{TiCl}_{6}\right]$ from the sticky solid obtained from the reactions of $\left[\mathrm{C}_{4} \mathrm{mim}\right] \mathrm{Cl}\left(3: 1,2: 1\right.$, and $1: 1$ ratios) and $\left[\mathrm{C}_{4} \mathrm{mim}\right] \mathrm{Br}\left(1: 1\right.$ ratio only) with $\mathrm{TiCl}_{4}$ have identical unit cell parameters. The structures of both complexes obtained from the bromide IL were solved and partial refinements of the data were used to analyze if partial $\mathrm{Cl} / \mathrm{Br}$ occupancy was present. Thermal parameters, $\mathrm{R}$-factors, and goodness of fit of the $\left[\mathrm{C}_{4} \mathrm{mim}\right]_{2}\left[\mathrm{TiCl}_{6}\right]$ and $\left[\mathrm{C}_{4} \mathrm{mim}\right]_{2}\left[\mathrm{Ti}_{2} \mathrm{Cl}_{10}\right]$ Form I structures obtained from the reaction with $\left[\mathrm{C}_{4} \mathrm{mim}\right] \mathrm{Br}$ strongly suggested that no $\mathrm{Br}^{-}$was present. A similar analysis was carried out for the structure from the $\left[\mathrm{C}_{4} \mathrm{mim}\right]\left[\mathrm{BF}_{4}\right]$ reaction, looking for partial $\mathrm{F} / \mathrm{Cl}$ occupancy and it was determined that the thermal parameters, R-factors, and goodness of fit of the structure strongly suggested the correct formula of the complex to be $\left[\mathrm{C}_{4} \mathrm{mim}\right]_{2}\left[\mathrm{Ti}_{4} \mathrm{~F}_{6} \mathrm{Cl}_{12}\right]$.

Powder X-ray diffraction (PXRD) data of the bulk materials (the mixtures of sticky solids and crystals obtained from the reactions of the ILs and $\mathrm{TiCl}_{4}$ ) were recorded on a Bruker D2 PHASER instrument with a Linxeye linear position-sensitive detector (BrukerAXS, Madison, WI) using Ni-filtered $\mathrm{Cu}-\mathrm{K} \alpha$ radiation. Sample preparation for the PXRD experiment was done in a glove bag under inert atmosphere. The bulk material was sticky and was placed as a thin layer on a silicon low background sample holder. A dome (BrukerAXS, Madison, WI) was placed over the sample holder and sealed against the O-ring. The diffraction data were measured across a $2 \theta$ range of 5 to $40^{\circ}$ using a continuous fast scanning mode with a rate of $0.5 \mathrm{~s} / 0.02^{\circ}$. A background measurement was also done for the airtight dome sealed holder with the same parameters. The data are in SI Figures S1-S4.

\section{Results}

\subsection{Observations on the Reactivity of $\mathrm{TiCl}_{4}$}

Reactions of $\left[\mathrm{C}_{4} \mathrm{mim}\right] \mathrm{Cl},\left[\mathrm{C}_{4} \mathrm{mim}\right] \mathrm{Br}$, and $\left[\mathrm{C}_{4} \mathrm{mim}_{3}\right] \mathrm{BF}_{4}$ with $\mathrm{TiCl}_{4}$ were conducted by directly combining the ILs and $\mathrm{TiCl}_{4}$, heating the components to $100{ }^{\circ} \mathrm{C}$ to achieve a homogeneous melt, and allowing them to cool. Both addition of the IL to $\mathrm{TiCl}_{4}$ and 
addition of $\mathrm{TiCl}_{4}$ to the IL were examined (Table 1). In all cases, the reactions proceeded vigorously with $\mathrm{HCl}$ gas evolution and a color change from colorless or pale yellow to dark yellow. Reactions with $\left[\mathrm{C}_{4} \mathrm{mim}\right] \mathrm{Cl}$ and $\mathrm{TiCl}_{4}$ yielded sticky solids upon cooling at $1: 1,2: 1$, and $3: 1$ ratios of $\left[\mathrm{C}_{4} \mathrm{mim}\right] \mathrm{Cl}$ to $\mathrm{TiCl}_{4}$ and yielded liquids with small amounts of crystalline solid at a $1: 3$ ratio of $\left[\mathrm{C}_{4} \mathrm{mim}\right] \mathrm{Cl}$ to $\mathrm{TiCl}_{4}$. $\left[\mathrm{C}_{4} \mathrm{mim}\right] \mathrm{Br}$ and $\left.\left[\mathrm{C}_{4} \mathrm{mim}\right] \mathrm{BF}_{4}\right]$ were reacted only at 1:1 ratios to give, respectively, solid and liquid reaction mixtures. Powder X-ray diffraction on all solid reaction mixtures indicated that they were primarily amorphous in all cases (see Figure S1 and S2), however all reactions also yielded single crystals as minor components that could be isolated by hand.

Table 1. Reactions and Crystallographically Characterized Products of the ILs with $\mathrm{TiCl}_{4}$.

\begin{tabular}{|c|c|c|c|c|}
\hline IL & $\begin{array}{c}\text { IL:TiCl } \\
\text { Molar } \\
\text { Ratio } \\
\end{array}$ & $\begin{array}{c}\text { Addition of } \mathrm{TiCl}_{4} \\
\text { to IL }\end{array}$ & $\begin{array}{c}\text { Addition of IL to } \\
\mathrm{TiCl}_{4}\end{array}$ & Crystals Obtained \\
\hline \multirow{4}{*}{$\stackrel{\left.\mathrm{C}_{4} \mathrm{mim}\right] \mathrm{Cl}}{\sim} \underset{\mathrm{N}}{\stackrel{\mathrm{Cl}^{+}}{\sim}}$} & $1: 1$ & \multirow{3}{*}{\multicolumn{2}{|c|}{$\begin{array}{l}\text { Sticky solid with crystals of } \\
\qquad\left[\mathrm{C}_{4} \mathrm{mim}\right]_{2}\left[\mathrm{TiCl}_{6}\right]\end{array}$}} & \multirow{3}{*}[\mathrm{C}_{4}\mathrm{mim}]{$_{2}\left[\mathrm{TiCl}_{6}\right]$} \\
\hline & $2: 1$ & & & \\
\hline & $3: 1$ & & & \\
\hline & $1: 3$ & $\begin{array}{l}\text { Liquid with a few } \\
\text { crystals of } \\
{\left[\mathrm{C}_{4} \mathrm{mim}\right]_{2}\left[\mathrm{TiCl}_{6}\right]}\end{array}$ & $\begin{array}{l}\text { Liquid with a few } \\
\text { crystals of } \\
{\left[\mathrm{C}_{4} \mathrm{mim}_{2}\left[\mathrm{Ti}_{2} \mathrm{Cl}_{10}\right]\right.} \\
\text { Form II }\end{array}$ & $\begin{array}{c}{\left[\mathrm{C}_{4} \mathrm{mim}\right]_{2}\left[\mathrm{Ti}_{2} \mathrm{Cl}_{10}\right]} \\
\text { Form II }\end{array}$ \\
\hline \multirow{2}{*}{$\underset{\left[\mathrm{C}_{4} \mathrm{mim}\right] \mathrm{Br}}{\sim \mathrm{Nr}_{-}^{-}}$} & \multirow{2}{*}{$1: 1$} & \multirow{2}{*}{$\begin{array}{l}\text { Sticky solid with } \\
\text { crystals of } \\
{\left[\mathrm{C}_{4} \mathrm{mim}\right]_{2}\left[\mathrm{TiCl}_{6}\right]}\end{array}$} & \multirow{2}{*}{$\begin{array}{c}\text { Sticky solid with } \\
\text { crystals of } \\
{\left[\mathrm{C}_{4} \mathrm{mim}_{2}\left[\mathrm{TiCl}_{6}\right] \text { and }\right.} \\
{\left[\mathrm{C}_{4} \mathrm{mim}_{2}\left[\mathrm{Ti}_{2} \mathrm{Cl}_{10}\right]\right.} \\
\text { Form I }\end{array}$} & {$\left[\mathrm{C}_{4} \mathrm{mim}\right]_{2}\left[\mathrm{TiCl}_{6}\right]$} \\
\hline & & & & $\begin{array}{c}{\left[\mathrm{C}_{4} \mathrm{mim}_{2}\left[\mathrm{Ti}_{2} \mathrm{Cl}_{10}\right]\right.} \\
\text { Form I }\end{array}$ \\
\hline$\left[\mathrm{C}_{4} \mathrm{mim}\right]\left[\mathrm{BF}_{4}\right]$ & $1: 1$ & \multicolumn{2}{|c|}{$\begin{array}{l}\text { Liquid with a few crystals of } \\
\qquad\left[\mathrm{C}_{4} \mathrm{mim}\right]_{2}\left[\mathrm{Ti}_{4} \mathrm{~F}_{6} \mathrm{Cl}_{12}\right]\end{array}$} & {$\left[\mathrm{C}_{4} \mathrm{mim}_{2}\left[\mathrm{Ti}_{4} \mathrm{~F}_{6} \mathrm{Cl}_{12}\right]\right.$} \\
\hline
\end{tabular}

Our observation that $\mathrm{TiCl}_{4}$ and $\left[\mathrm{C}_{4} \mathrm{mim}\right] \mathrm{Cl}$ gave a sticky solid reaction mixture conflicted with prior reports that this reaction should give a room temperature liquid ${ }^{58}$ or that pure $\left[\mathrm{C}_{4} \mathrm{mim}\right]_{2}\left[\mathrm{Ti}_{2} \mathrm{Cl}_{10}\right]$ was a crystalline solid. ${ }^{39}$ In order to avoid supercooling, we also attempted 1:1 molar reactions of $\mathrm{TiCl}_{4}$ at room temperature using hand grinding in an agate mortar and pestle to drive the reaction, which led to homogeneous yet amorphous solid powders (see Figure $\mathrm{S} 3$ ) for $\left[\mathrm{C}_{4} \mathrm{mim}\right] \mathrm{Cl}$ and $\left[\mathrm{C}_{4} \mathrm{mim}\right] \mathrm{Br}$ and to a dark orange liquid for $\left[\mathrm{C}_{4} \mathrm{mim}\right]\left[\mathrm{BF}_{4}\right]$. We attempted to induce a solid-to-solid phase transition of the amorphous material by grinding seed crystals of $\left[\mathrm{C}_{4} \mathrm{mim}\right]_{2}\left[\mathrm{Ti}_{2} \mathrm{Cl}_{10}\right]$ into them, but this resulted in no observable changes in the PXRD pattern of the material (see Figure S4). Overall, the amorphous solids obtained in this study appear to show exceptional 
stability, although prior reports of the isolation of crystalline complexes with these compositions, ${ }^{40,41}$ suggest they should be metastable with respect to the crystalline complexes.

The outcomes of reactions of $\mathrm{TiCl}_{4}$ with $\left[\mathrm{C}_{4} \mathrm{mim}\right]^{+}$halides appear to be rather poorly correlated with the identity of the IL and the ratio of $\mathrm{TiCl}_{4}$ to halide, both within our study and across the published literature. Instead, the systems appear to be particularly sensitive to how they were prepared. We hypothesize that this behavior has a kineticmolecular explanation: Within the homogenous reaction mixture, collisions between $\mathrm{Ti}^{4+}$ containing species and $\mathrm{Cl}^{-}$are the least likely because the volume of $\mathrm{Cl}^{-}$is so much smaller relative to the other species. When anionic chlorotitanates do form, they are more likely to collide with $\mathrm{TiCl}_{4}$ and result in the formation of multinuclear anions with low charge. It has been shown that the viscosity of chlorotitanate ILs is well-accounted for by the hole theory of liquids, ${ }^{63}$ so the formation of multinuclear halotitantes provides a mechanism for vitrification. This hypothesis also explains the crystallization of species such as $\left[\mathrm{C}_{2} \mathrm{mim}\right]_{2}\left[\mathrm{TiCl}_{6}\right]$ from systems that have excess $\mathrm{Ti}^{4+}$; the competing reaction of $\mathrm{TiCl}_{4}$ with anionic chlorotitanates depletes the system of $\mathrm{TiCl}_{4}$ faster than $\mathrm{Cl}^{-}$. When crystals form, it is ultimately in a system where free $\left[\mathrm{C}_{4} \mathrm{mim}\right] \mathrm{Cl}$ is in excess relative to free $\mathrm{TiCl}_{4}$. The variable identities of the crystals thus reflect the fact that when they grow, the composition of the liquid has already changed due to vitrefaction.

In contrast to the reactions with halide ILs, when reacted at a 1:1 ratio, $\left[\mathrm{C}_{4} \mathrm{mim}\right]\left[\mathrm{BF}_{4}\right]$ and $\mathrm{TiCl}_{4}$ yielded a liquid which only gave crystals identified as $\left[\mathrm{C}_{4} \mathrm{mim}\right]_{2}\left[\mathrm{Ti}_{4} \mathrm{~F}_{6} \mathrm{Cl}_{12}\right]$ upon storage at $0{ }^{\circ} \mathrm{C}$ for several days. These crystals were reproducibly isolated in separate experiments irrespective of the order of addition of $\mathrm{IL}$ and $\mathrm{TiCl}_{4}$. The source of the fluoride anions must be the $\left[\mathrm{BF}_{4}\right]^{-}$anion, as the starting $\left[\mathrm{C}_{4} \mathrm{mim}\right]\left[\mathrm{BF}_{4}\right]$ was analyzed for free fluoride anion content by ion chromatography and found to contain less than 1 ppm free fluoride. There is the possibility that small amounts of $\mathrm{F}^{-}$formed by hydrolysis of $\left[\mathrm{C}_{4} \mathrm{mim}\right]\left[\mathrm{BF}_{4}\right],{ }^{64}$ however, because $\mathrm{Ti}^{4+}$ like $\mathrm{B}^{3+}$, is a hard Lewis acid, halide anion transfers between $\mathrm{BX}_{\mathrm{n}}$ and $\mathrm{TiX}_{\mathrm{m}}$ of the type shown in eq. 1 are known: ${ }^{65}$

$$
\mathrm{F}_{3} \mathrm{~B}-\mathrm{F}^{-}+\mathrm{TiCl}_{4} \rightarrow \mathrm{F}_{3} \mathrm{~B}+\mathrm{F}-\mathrm{TiCl}_{4}^{-}
$$

It has also been shown that even without the presence of metal ions, 1,3dialkylimidazolium $\left[\mathrm{BF}_{4}\right]^{-}$ILs can thermally decompose into $\mathrm{HF}$ and the ylidene- $\mathrm{BF}_{3}$ adduct. ${ }^{66}$ Further halide exchanges allow equilibration across various boron and titanium polyhalide molecules and polyhalide anions, leading eventually to the thermodynamically favored $\left[\mathrm{Ti}_{4} \mathrm{~F}_{6} \mathrm{Cl}_{12}\right]^{2-}$. Interestingly while the deprotonation of dialkylimidazolium cations in metal-containing IL systems is known, ${ }^{67}$ it has only been described as a source of carbene complexes and not yet reported to explain the speciation of metal halides in an IL.

\subsection{Observations on the Crystal Structures}

A summary of the crystallographic results is presented in Table 1. We will first summarize the structures obtained and then discuss the implications of these results on the Lewis acidity of $\mathrm{Ti}^{4+}$ and the basicity of the resulting halotitanate species.

\section{$3.3\left[\mathrm{C}_{4} \mathrm{mim}\right]_{2}\left[\mathrm{TiCl}_{6}\right]$}


The crystal structure of $\left[\mathrm{C}_{4} \mathrm{mim}\right]_{2}\left[\mathrm{TiCl}_{6}\right]$ was solved in the orthorhombic space group $P 2{ }_{1} 2_{1} 2_{1}$ and contains one unique formula unit per asymmetric unit (Fig. 1). Both cations have butyl groups disordered over two mostly overlapping positions which are oriented nearly perpendicular to the imidazolium ring plane. The crystal packing of $\left[\mathrm{C}_{4} \mathrm{mim}\right]_{2}\left[\mathrm{TiCl}_{6}\right]$ is virtually identical to $\left[\mathrm{C}_{4} \mathrm{mim}_{2}\left[\mathrm{ZrCl}_{6}\right],{ }^{11}\right.$ which was solved in the lower symmetry space group $P 2$, however, we believe the higher symmetry space group $P 2{ }_{1}{ }_{1}{ }_{2}{ }_{1}$ is correct, even with disorder in the $\left[\mathrm{C}_{4} \mathrm{mim}\right]^{+}$cations.

In this structure, each of the two unique cations is surrounded by four anions which make short contacts (defined as two atoms within a distance of less than the sum of the van der Waals radii) to one or two hydrogen atoms each to the imidazolium ring and butyl chain, roughly in the plane of the ring (Fig. 1b). In dialkylimidazolium salts, Coulombic interactions tend to occur between anions and carbon atoms and are perpendicular to the plane of the ring ${ }^{68}$ while in-plane interactions to ring hydrogen atoms are typically assigned to hydrogen bonding, even for weakly Lewis basic halometallates such as $\left[\mathrm{AlCl}_{4}\right]^{-69}$. The environments around the two cations are very similar. The anion makes short contacts to eight cations which form two sheets above and below the anion (Fig. 1c). The arrangement nearly has four-fold symmetry, consistent with the nearly tetragonal lattice constants, but the symmetry-inequivalent cations have their butyl groups on the wrong sides of the ring relative to each other and thus cannot be related by 4 -fold rotation. Overall the structure approximates a $\mathrm{CsCl}$ lattice with the two cations acting as a pseudo-dication (Figure S5).

The $\left[\mathrm{TiCl}_{6}\right]^{2-}$ anion is distorted octahedral with axial Ti-Cl bonds (Ti-Cl5 $=2.353(1)$ $\AA$; Ti-Cl3 = 2.353(1) $\AA$ ) longer than the equatorial Ti-Cl bonds (Ti-Cl1 = 2.334(1) $\AA$; Ti$\mathrm{Cl} 2=2.343(1) \AA ;$ Ti-Cl4 = 2.336(1) $\AA$, Ti-Cl6 = 2.339(1) $\AA$ ). This same axial lengthening of two $\mathrm{Ti}-\mathrm{Cl}$ bonds is observed in the crystal structure of $\left[\mathrm{C}_{4} \mathrm{mim}\right]_{2}\left[\mathrm{TiCl}_{6}\right] \cdot \mathrm{CH}_{2} \mathrm{Cl}_{2}{ }^{41}$ and $\left[\mathrm{C}_{4} \mathrm{mim}\right]_{2}\left[\mathrm{ZrCl}_{6}\right]$, although to a lesser degree. The fact that this small distortion is conserved across multiple structures argues that it is the result of a significantly stabilizing packing effect. The reported crystal structures of $\left[\mathrm{C}_{4} \mathrm{mim}\right]_{2}\left[\mathrm{TiCl}_{6}\right] \cdot \mathrm{CH}_{2} \mathrm{Cl}_{2}$ and $\left[\mathrm{C}_{4} \mathrm{mim}\right]_{2}\left[\mathrm{ZrCl}_{6}\right]$ argue that the stabilization of this type of structure is substantial.

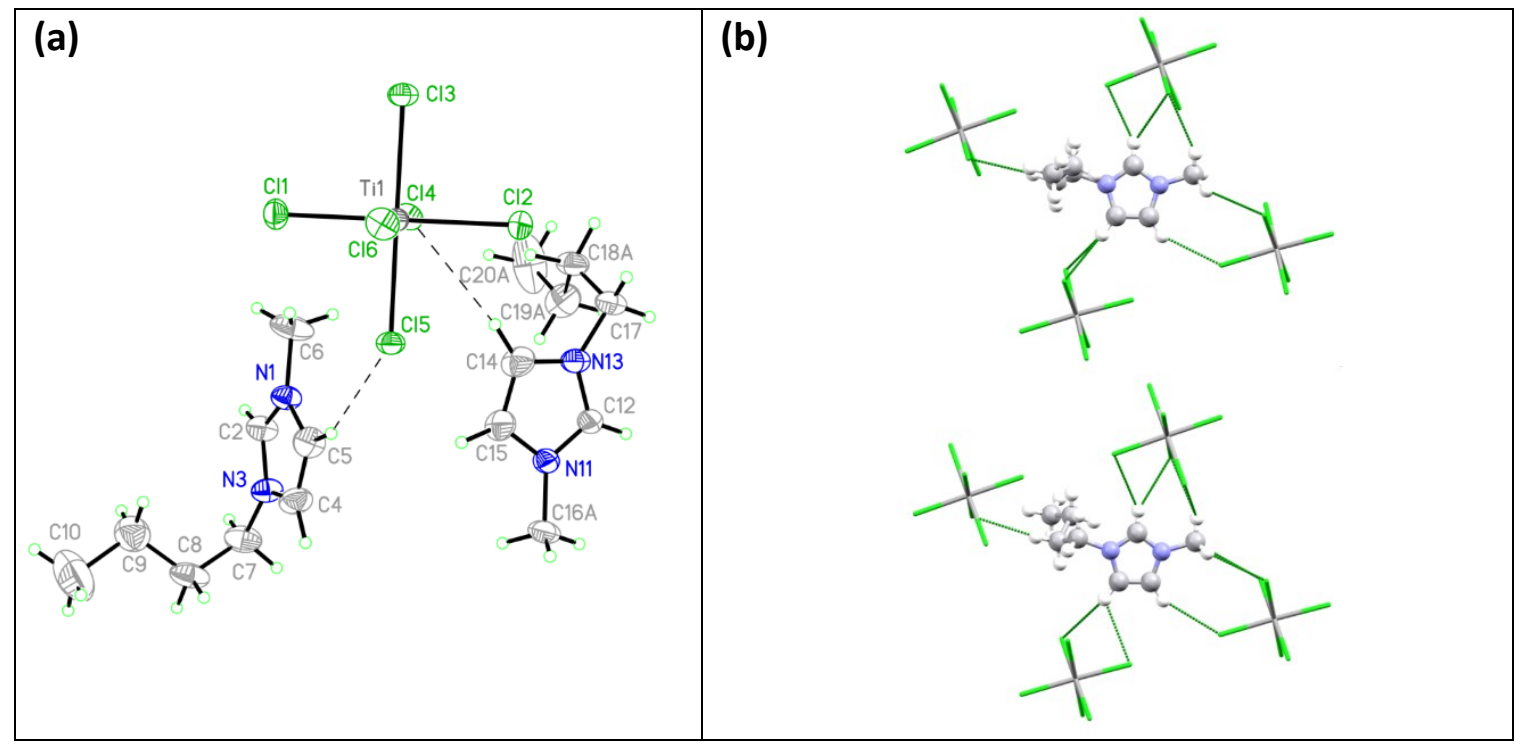




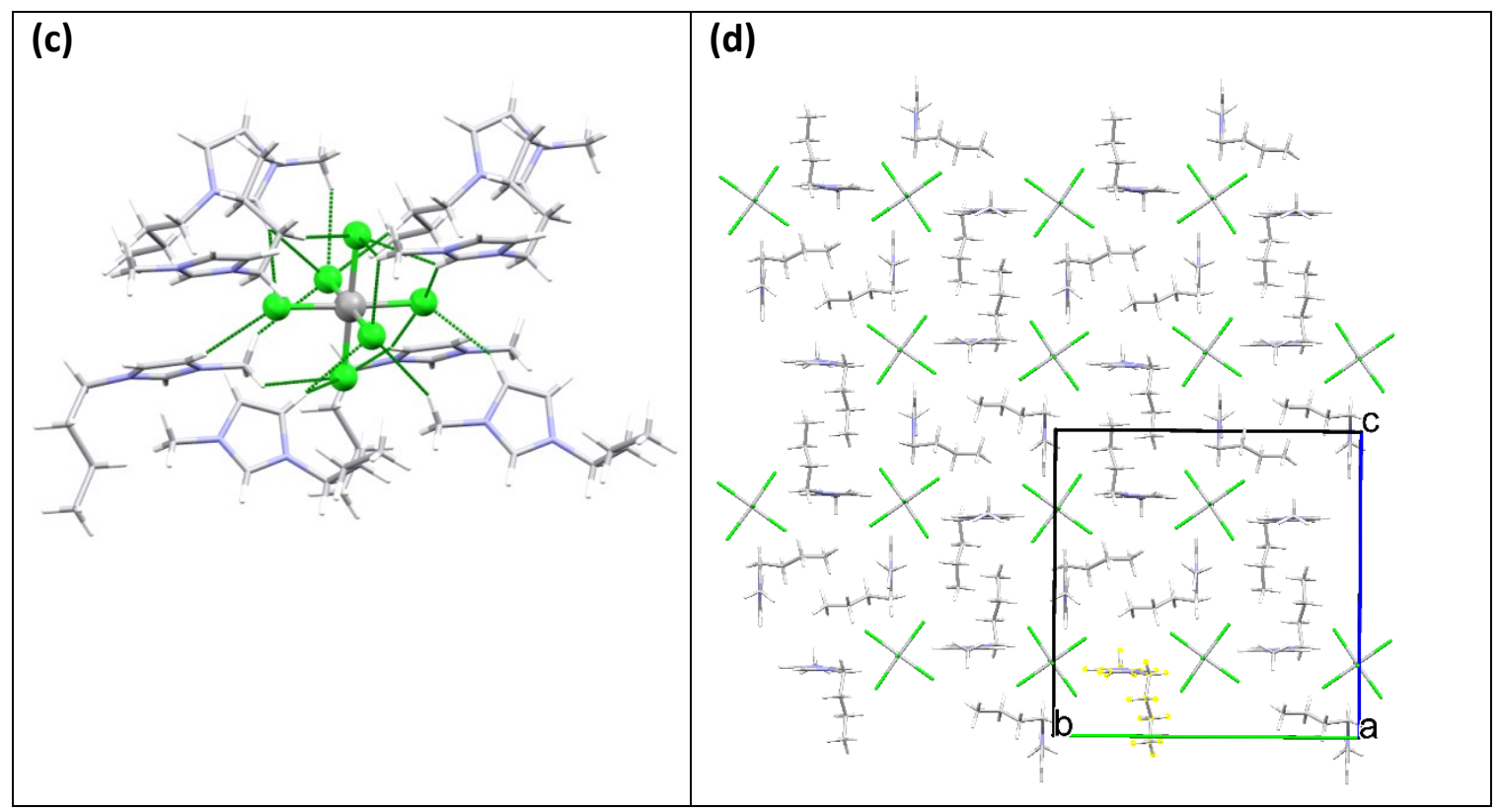

Figure 1: $50 \%$ Probability ellipsoid plot of the formula unit of $\left[\mathrm{C}_{4} \mathrm{mim}\right]_{2}\left[\mathrm{TiCl}_{6}\right]$ (a). Packing diagrams showing short (less than the sum of the van der Waals radii) contacts to each unique cation (b) and anion (c). The dashed green lines indicate short contacts. Packing diagram showing $2 \times 2 \times 2$ unit cells viewed down the crystallographic $a$ axis (d). The disorder has been omitted for clarity.

\section{$3.4\left[\mathrm{C}_{4} \mathrm{mim}\right]_{2}\left[\mathrm{Ti}_{2} \mathrm{Cl}_{10}\right]$}

This compound was isolated as both the known form of $\left[\mathrm{C}_{4} \mathrm{mim}\right]_{2}\left[\mathrm{Ti}_{2} \mathrm{Cl}_{10}\right]^{39}$ (here Form I) and a new polymorph (Form II). The reported Form I crystallizes in the monoclinic space group $P 2_{1} / n$ with one $\left[\mathrm{C}_{4} \mathrm{mim}\right]^{+}$cation and half a binuclear $\left[\mathrm{Ti}_{2} \mathrm{Cl}_{10}\right]^{2-}$ anion in the asymmetric unit connected through $\mathrm{C}-\mathrm{H} \cdots \mathrm{Cl}$ interactions. Form II also crystallized in $P 2{ }_{1} / n$ with one cation and one half of the anion in the asymmetric unit (Fig 2a). The binuclear anion is slightly skewed about its center. The butyl chain of the cation is an all-anti configuration with the two disordered carbon atoms.

Each cation makes short contacts to four cations and four anions (Fig $\mathbf{2 b}$, top), while each anion makes short contacts to eight cations and no anions (Fig $\mathbf{2 b}$, bottom). The cation-anion pairs are connected through $\mathrm{C}-\mathrm{H} \cdots \mathrm{Cl}$ hydrogen bonds donated by hydrogen atoms on the imidazolium ring, the methyl and methylene groups $\alpha$ to the nitrogen atoms, and the methylene group $\beta$ to the nitrogen atom. The short cation-cation contacts involve the two disorder carbon atoms at the end of the butyl chain possibly indicating repulsive interactions. 


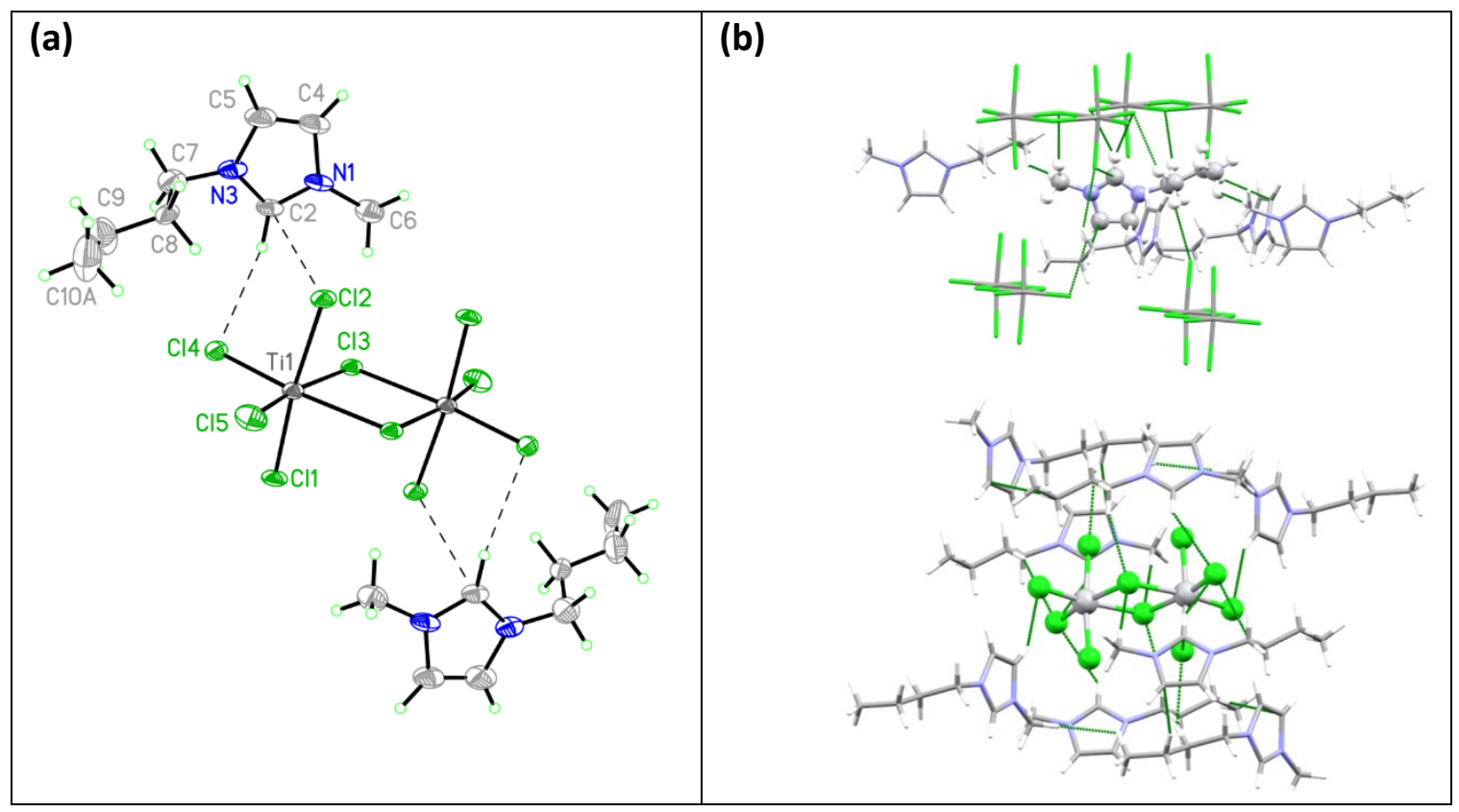

Figure 2. 50\% probability ellipsoid plot of the formula unit of $\left[\mathrm{C}_{4} \mathrm{mim}\right]_{2}\left[\mathrm{Ti}_{2} \mathrm{Cl}_{10}\right]$ (Form II) (a). Non-labeled atoms are symmetry equivalents of labeled atoms. Packing diagrams showing short contact environments around the cation (top) and anion (bottom) in Form II (b). Dashed green lines indicate short contacts. The disorder has been omitted for clarity.

Form I and II are packing polymorphs. ${ }^{70}$ In Form II, the cations are oriented so that they lie in between two anions, with the imidazolium ring plane roughly parallel to the $\mathrm{Ti}-\mathrm{Cl}$ bond and the $\mathrm{C} 2-\mathrm{H}$ bond pointing towards the equatorial plane of $\mathrm{Cl}^{-}$ligands. This orientation appears to maximize the out-of-plane $\mathrm{C} 2 \cdots \mathrm{Cl}$ interactions, which is generally the strongest electrostatic interaction in 1,3-dialkylimidazolium salts, ${ }^{71}$ while also allowing hydrogen bonding to the $\mathrm{C} 2-\mathrm{H}$ hydrogen atom, which is the most acidic. This bridges the cations and anions into infinite chains along the crystallographic $b$ axis (Fig. 3a). By contrast, in $\left[\mathrm{C}_{4} \mathrm{mim}\right]_{2}\left[\mathrm{Ti}_{2} \mathrm{Cl}_{10}\right]$ Form $\mathrm{I}$, the cation is oriented so that it overlaps with the bridging, rather than the axial, chlorides. This leads to maximized hydrogen bonding with no short contacts related to Coulombic stacking in Form I as compare to Form II (Fig. 3b). 


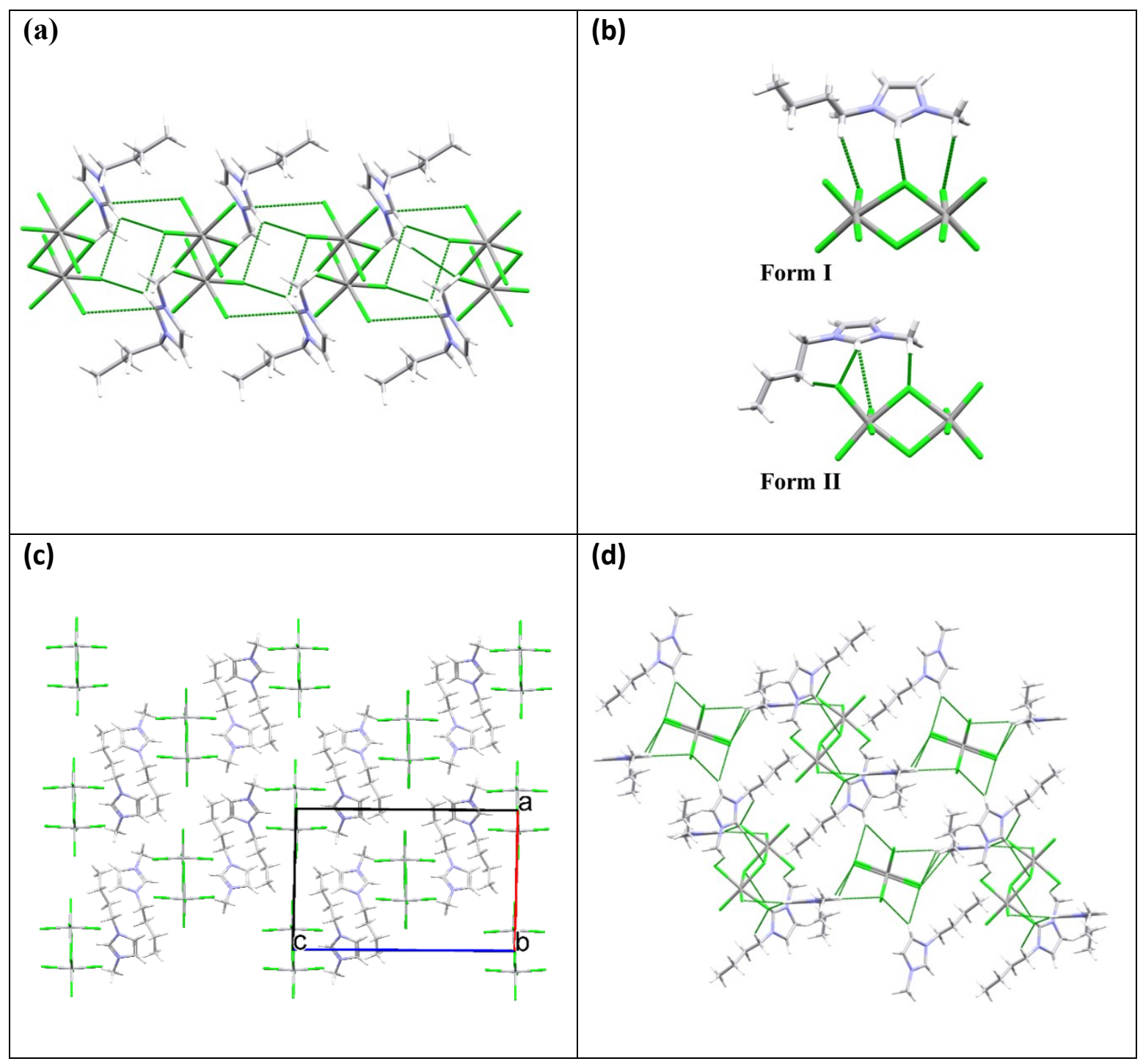

Figure 3. Packing diagrams of $\left[\mathrm{C}_{4} \mathrm{mim}\right]_{2}\left[\mathrm{Ti}_{2} \mathrm{Cl}_{10}\right]$ Form II (a) showing organization of anions and cations into infinite chains along the crystallographic $b$ axis through interactions with C2 (dashed green lines indicate short contacts). Comparison of the two most closely associated ions in Form I vs. Form II (b). Packing diagram of Form II in $2 \times 2 \times 2$ unit cells viewed down the $b$ axis (c) and Form I viewed down the $b c$ plane (d) showing hydrogen bonded sheets. Dashed green lines in Form I indicate short contacts. Disorder omitted for clarity.

The infinite chains in Form II (Fig 3a) arrange into infinite sheets perpendicular to the $a c$ diagonal, which stack by interacting through weaker hydrogen bonds involving the butyl chain (Fig. 3c). On the other hand, the cation-anion hydrogen bonds in Form I lead to the formation of hydrogen bonded sheets that stack along the ac diagonal (Fig. 3d). The sheets interact with each other through weaker hydrogen bonds involving the methyl groups $\alpha$ to the nitrogen atoms.

The Ti(IV) cations in Form I adopt a distorted octahedral geometry with adjacent ClTi- $\mathrm{Cl}$ angles ranging from $78.64(7)^{\circ}$ for the angle across the bridging chlorides, to 
101.36(9) ${ }^{\circ}$ for the angle trans to this. In Form II, the unique $\mathrm{Ti}^{4+}$ center has a slightly less distorted octahedral geometry as compare to Form I, with adjacent Cl-Ti-Cl angles ranging from $79.05(8)^{\circ}$, for the angle between the bridging chlorides, to $100.71(11)^{\circ}$ for the angle trans to this.

\section{$3.5\left[\mathrm{C}_{4} \mathrm{mim}\right]_{2}\left[\mathrm{Ti}_{4} \mathrm{~F}_{6} \mathrm{Cl}_{12}\right]$}

This structure is triclinic $P-1$ with an asymmetric unit consisting of two $\left[\mathrm{C}_{4} \mathrm{mim}\right]^{+}$ cations and the cage anion $\left[\mathrm{Ti}_{4} \mathrm{~F}_{6} \mathrm{Cl}_{12}\right]^{2-}$ (Fig. 4a). Butyl groups of both cations are oriented nearly perpendicular to the imidazolium ring plane, although the last two carbon atoms of one cation are disordered over two slightly offset positions. The cage structure comprises a tetrahedral arrangement of $\mathrm{Ti}^{4+}$ cations, with all six edges of the tetrahedron formed by $\mathrm{F}^{-}$ligands each bridging two $\mathrm{Ti}^{4+}$ cations. Three terminal $\mathrm{Cl}^{-}$ligands cap each $\mathrm{Ti}^{4+}$ such that each titanium ion has a distorted octahedral coordination geometry. The $\mathrm{Ti} \cdots \mathrm{Ti}$ distances range from 3.838(6) to 3.848(7) $\AA$.

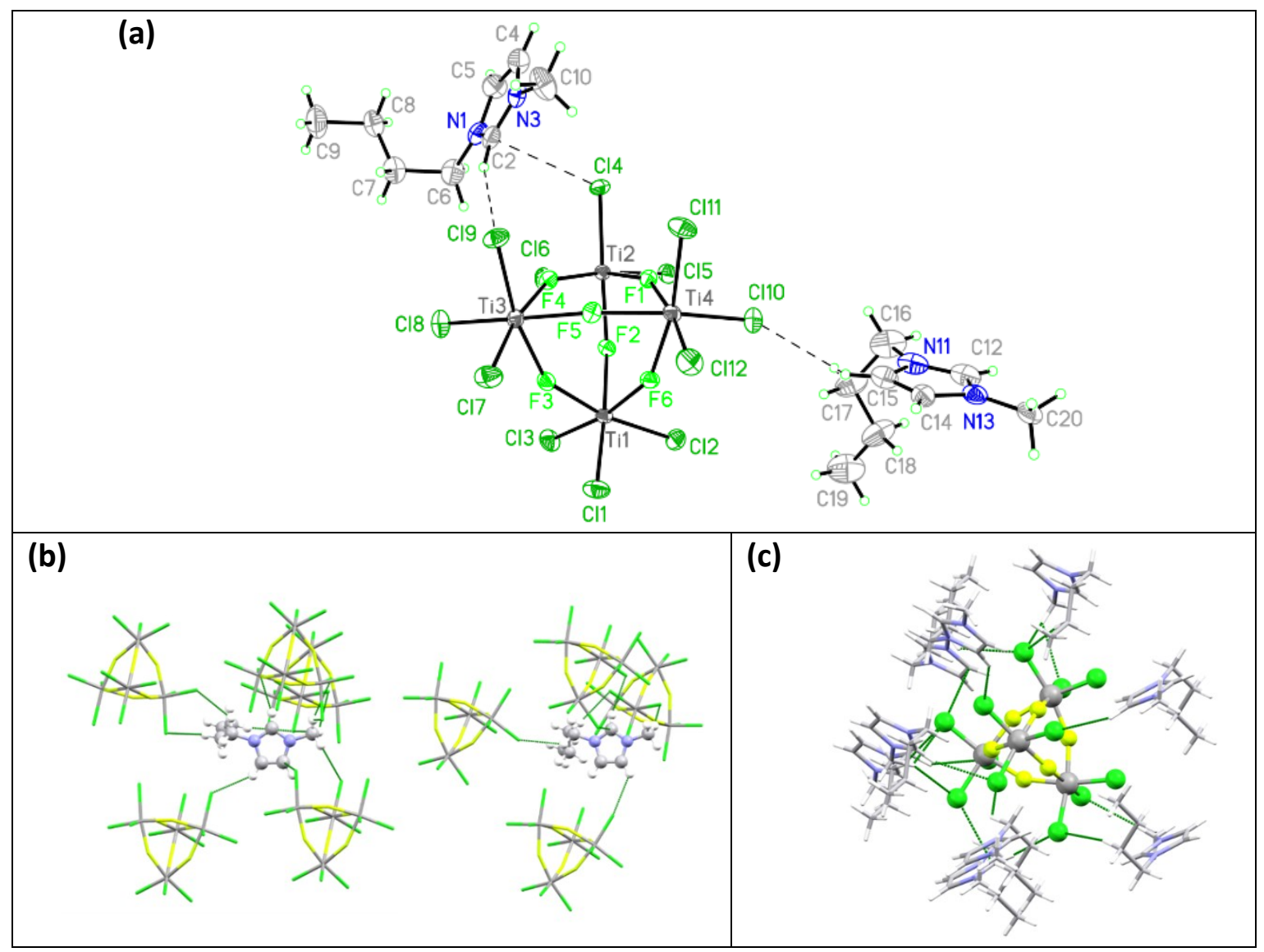




\section{(d)}

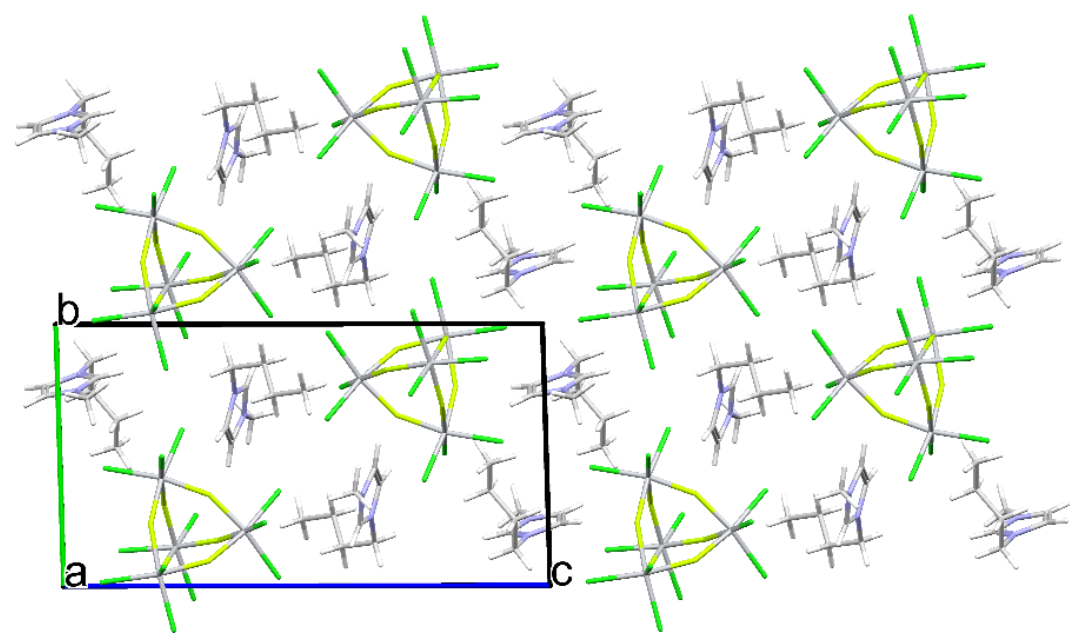

Figure 4. $50 \%$ probability ellipsoid plot of the formula unit of $\left[\mathrm{C}_{4} \mathrm{mim}_{2}\left[\mathrm{Ti}_{4} \mathrm{~F}_{6} \mathrm{Cl}_{12}\right]\right.$ (a). Packing diagrams showing short contacts to each unique cation (b) and the anion (c). Dashed green lines indicate short contacts. Packing diagram showing $2 \times 2 \times 2$ unit cells viewed down crystallographic $a$ axis (d). The disorder has been omitted for clarity.

A similar cage structure has been reported for the tetranuclear $\left[\mathrm{Ti}_{4} \mathrm{~F}_{18}\right]^{2-}$ anion. ${ }^{72-73,74}$ The Ti-F distances for the bridging fluoride anions in these reported structures are longer (ranging from 1.959(4) to 2.019(4) $\AA$ ) than the terminal Ti-F distances (ranging from $1.752(4)$ to $1.790(4) \AA$ ). The bridging Ti-F bond distances in $\left[\mathrm{Ti}_{4} \mathrm{~F}_{6} \mathrm{Cl}_{12}\right]^{2-}(1.967(5)$ to $1.997(5) \AA)$ fall into the same range for bridging fluoride anions. The Ti-Cl range from 2.206(3) to 2.239(3) $\AA$, which is somewhat shorter than the terminal Ti-Cl distances previously observed in the $\left[\mathrm{Ti}_{2} \mathrm{Cl}_{10}\right]^{2-}$ anion $(2.227$ to $2.317 \AA) .{ }^{39,40}$ This is likely due to the high electronegativity of fluorine, which leads to a higher fractional positive charge on titanium in $\left[\mathrm{Ti}_{4} \mathrm{~F}_{6} \mathrm{Cl}_{12}\right]^{2-}$, which in turn leads to a stronger interaction with the bound chlorides.

One cation makes short contacts to four anions, while the other makes short contacts to five anions (Fig. 4b). The anion makes short contacts to nine cations (Fig. 4c), and there are no short contacts between like ions. ${ }^{75}$ The packing essentially consists of charge-ordered columns of cations or anions along the crystallographic $a$-axis which are bridged by these interactions along $b$ - and $c$-axes into a 3D network (Fig. 4d). It also appears that the butyl groups of one of the unique cations form narrow, continuous lipophilic channels along the crystallographic $b$-axis while the butyl groups of the other cation do not appear to aggregate.

\section{Discussion of Lewis acidity of $\mathrm{Ti}^{4+}$ and Basicity of the Halotitanate Species}

It is interesting to note here two additional crystalline phases were obtained from the reactions of $\mathrm{TiCl}_{4}$ with $\left[\mathrm{C}_{4} \mathrm{mim}\right] \mathrm{Cl}$ and the $1: 1$ reaction of $\mathrm{TiCl}_{4}$ with $\left[\mathrm{C}_{4} \mathrm{mim}\right] \mathrm{Br}$, respectively (see Table 1). These two additional crystalline phases were found to be polymorphs of the compound $\left[\mathrm{C}_{4} \mathrm{mim}\right]_{2}\left[\mathrm{Ti}_{2} \mathrm{Cl}_{10}\right]$. Polymorphism is prevalent in $\left[\mathrm{C}_{4} \mathrm{mim}\right]^{+}$ salts, but is usually correlated with conformational flexibility of the cation. ${ }^{76}$ 
Interestingly, in both forms of $\left[\mathrm{C}_{4} \mathrm{mim}\right]_{2}\left[\mathrm{Ti}_{2} \mathrm{Cl}_{10}\right]$ the conformations of all ions are similar, and it is the relative orientations of the ions which differs between the two.

The bond distance differences with the four mono-coordinated chlorides of the Form II $\left[\mathrm{Ti}_{2} \mathrm{Cl}_{10}\right]^{2-}$ anion range from 2.231(3) to 2.306(3) $\AA$, while the bridging chlorides show longer bond lengths of 2.472(3) and 2.512(3) $\AA$. These structural features have all been noted in other crystalline salts containing $\left[\mathrm{Ti}_{2} \mathrm{Cl}_{10}\right]^{2-} .{ }^{-77}$ This may account for the higher Lewis acidity of the $\left[\mathrm{Ti}_{2} \mathrm{Cl}_{10}\right]^{2-}$ anion than the $\left[\mathrm{TiCl}_{6}\right]^{-}$anion as the elongated bridging Ti$\mathrm{Cl}$ bonds will leave the Ti center coordinatively partially unsatisfied.

The formation of $\left[\mathrm{Ti}_{4} \mathrm{~F}_{6} \mathrm{Cl}_{12}\right]^{2-}$ from $\left[\mathrm{C}_{4} \mathrm{mim}\right]\left[\mathrm{BF}_{4}\right]$ and $\mathrm{TiCl}_{4}$ has implications for other reactions that utilize this mixture such as the reported hydrolysis of a solution of $\mathrm{TiCl}_{4}$ in $\left[\mathrm{C}_{4} \mathrm{mim}\right]\left[\mathrm{BF}_{4}\right]$ to yield $\mathrm{TiO}_{2}$ nanoparticles with the anatase structure. ${ }^{78} \mathrm{In}$ contrast, a similar hydrolysis of $\mathrm{TiCl}_{4}$ in $\left[\mathrm{C}_{4} \mathrm{mim}\right] \mathrm{Cl}$ under similar conditions leads to a mixture of anatase and rutile $\mathrm{TiO}_{2}$, which eventually converts to pure rutile $\mathrm{TiO}_{2}{ }^{79}$ The presence of $\left[\mathrm{Ti}_{4} \mathrm{~F}_{6} \mathrm{Cl}_{12}\right]^{2-}$ or similar mixed fluoride-chloride species in $\left[\mathrm{C}_{4} \mathrm{mim}\right]\left[\mathrm{BF}_{4}\right]$ may slow the hydrolysis and lead to anatase $\mathrm{TiO}_{2}$ exclusively.

The possibility of disproportionation or substitution between the metal halide has not received much consideration in determining the speciation of Lewis acidic halometallate ILs as it is not very intuitive. The high vapor pressure and low conductivity of pure $\mathrm{TiCl}_{4}$ would suggest that it does not autoionize to any significant extent, and the phase diagrams of halide ILs with the more well-studied Lewis acid metal chloride $\mathrm{AlCl}_{3}$, indicate that there is simply a ratio-dependent addition of $\mathrm{Cl}^{-}$to $\mathrm{AlCl}_{3}{ }^{7}$ However, it may offer insight into the reason why electroplating $\operatorname{Ti}(0)$ from ILs has been a particular challenge. ${ }^{80}$

The disproportionation is also important to consider in mixed-halide systems. In the literature, a random statistical distribution of $\mathrm{Br}^{-}$anions in the metal chloride complexes of $\mathrm{Al}^{3+}$ or $\mathrm{Bi}^{3+}$ is known on simple addition of $\mathrm{Br}^{-}$to salts of these metals. ${ }^{81,82}$ However, in the case of $\mathrm{TiCl}_{4}$ here, the Lewis acidity of $\mathrm{Ti}^{4+}$ drives it to maximize the number of the strongest interactions possible per metal ion, i.e. Ti-Cl, even in the presence of excess $\mathrm{Br}^{-}$as in the reactions with $\left.\left[\mathrm{C}_{4} \mathrm{mim}\right] \mathrm{Br}\right]$.

The contrast between the polymorphic behavior of $\left[\mathrm{C}_{4} \mathrm{mim}_{2}\left[\mathrm{Ti}_{2} \mathrm{Cl}_{10}\right]\right.$ with the crystallization of $\left[\mathrm{C}_{4} \mathrm{mim}_{2}\left[\mathrm{TiCl}_{6}\right]\right.$ as part of an isomorphous series, highlights the effect of size-to-charge ratio on the basicity of halometallates. The increase in size from $\left[\mathrm{TiCl}_{6}\right]^{2-}$ to $\left[\mathrm{Ti}_{2} \mathrm{Cl}_{10}\right]^{2-}$ with no corresponding increase in charge is correlated with the onset of crystal polymorphism caused entirely by differences in the packing of molecules, not their conformation or molecular structure. Polymorphism has been directly implicated as a melting point lowering mechanism in ILs. ${ }^{71}$ Halometallate complexes with highly acidic ions like $\mathrm{Ti}^{4+}$ may be useful in exploring this phenomenon, as the geometry of the molecules themselves tends to be highly conserved with other structures due to the strength of the metal-halide bonds.

\section{Conclusions}

The results of this study indicate a number of deviations from typical halometallate chemistry in ILs which are apparently driven by the high acidity of the $\mathrm{Ti}^{4+}$ ion and the strength of the resulting Ti-halide bonds. The reaction of $\mathrm{TiCl}_{4}$ with halide or $\left[\mathrm{BF}_{4}\right]^{-} \mathrm{ILs}$ led to the crystallization of $\left[\mathrm{TiCl}_{6}\right]^{2-},\left[\mathrm{Ti}_{2} \mathrm{Cl}_{10}\right]^{2-}$, or $\left[\mathrm{Ti}_{4} \mathrm{~F}_{6} \mathrm{Cl}_{12}\right]^{2-}$. These crystallizations indicate disproportionation or, in the case of $\left[\mathrm{BF}_{4}\right]^{-}$, substitution reactions that disrupt the 
ratio of $\mathrm{TiCl}_{4}$ to the IL. Such disproportionations are not generally considered when determining the role of speciation in the catalytic activity of halometallate ILs (even for those based on $\mathrm{Ti}^{4+}$ ). Our results indicate the importance of the high Lewis acidity of the metal in maximizing the thermodynamically favored strong interactions during the crystallization of the stable halotitanate complexes from the mixture of $\mathrm{TiCl}_{4}$ and ILs. The pure crystalline halotitanate complexes reported here warrant further investigation by differential scanning calorimetry to quantitatively relate the polymorphism behavior seen here to melting point. The $\mathrm{Cl}^{-}$-depleted liquids left behind after crystallization are also relevant as they may contain unusual species such as cation $\mathrm{Ti}^{4+}$ complexes or free IL ions solvated by $\mathrm{TiCl}_{4}$. However, the isolation of these compounds in order to do such characterization remains a challenge due to their reactivity and, moreover, the fact that nearly any solvent which can be used in a work-up is likely to perturb the speciation and equilibria of interest.

\section{Conflicts of Interest}

There are no conflicts to declare.

\section{ASSOCIATED CONTENT}

Electronic supplementary information: The Supporting Information is available free of charge on the ACS Publications website at DOI: 10.1021/acs.inorgchem.xxxxxx. PXRD analysis and additional figures of crystal packing (PDF).

\section{Accession Codes}

CCDC1824492-1824494 contain the supplementary crystallographic data for this paper. These data can be obtained free of charge via www.ccdc.cam.ac.uk/data request/cif, or by emailing data request@ccdc.cam.ac.uk, or by contacting The Cambridge Crystallographic Data Centre, 12 Union Road, Cambridge CB2 1EZ, UK; fax: +44 1223 336033.

\section{AUTHOR INFORMATION Corresponding Authors}

*E-mail: rdrogers@ua.edu

\section{ORCID}

Manish Kumar Mishra: 0000-0002-8193-3499

Steven P. Kelley: 0000-0001-6755-4495

Meghna Dilip: 0000-0003-3773-5396

Thomas P. Vaid: 0000-0003-4597-0847

David B. Cordes: 0000-0002-5366-9168

Robin D. Rogers: 0000-0001-9843-7494

\section{Present Address}

$\$$ S.P.K.: Department of Chemistry, University of Missouri, Columbia, MO 65211, USA 
${ }^{\dagger}$ M.D.: Department of Chemistry, Worcester State University, Worcester, MA 01602, USA

${ }^{\S}$ T.P.V.: Department of Chemistry, University of Michigan, Ann Arbor, MI 48109, USA

${ }^{\#}$ D.B.C.: School of Chemistry, University of St Andrews, St Andrews, KY16 9ST, UK

${ }^{¥}$ S.T.G.: Cytec Solvay Group, 1937 West Main St. Stamford, CT 06902, USA

Notes

The authors declare no competing financial interest.

\section{References}

1 Plechkova, N. V.; Seddon, K. R. Ionic Liquids: "Designer" Solvents for Green Chemistry. In Methods and Reagents for Green Chemistry: An Introduction; Tunod, P.; Peroso, A.; Zecchini, F., Eds.; John Wiley \& Sons: Hoboken, 2007; p.105-129.

2 Chatel, G.; Pereira, J. F. B.; Debbeti, V.; Wang, H.; Rogers, R. D. Mixing Ionic Liquids - "Simple Mixtures" or "Double Salts"?. Green Chem. 2014, 16, 2051-2083.

3 Estager, J.; Holbrey, J. D.; Swadźba-Kwaśny, M. Halometallate Ionic Liquids-Revisited. Chem. Soc. Rev. 2014, 43, 847-886.

4 Mandai, T.; Yoshida, K.; Ueno, K.; Dokko, K.; Watanabe, M. Criteria for Solvate Ionic Liquids. Phys. Chem. Chem. Phys. 2014, 16, 8761-8772.

5 Coleman, F.; Srinivasian, G.; Swadźba-Kwaśny, M. Liquid Coordination Complexes Formed by the Heterolytic Cleavage of Metal Halides. Angew. Chem. Int. Ed. 2013, $52,12582-12586$.

6 Abbott, A. P.; Capper, G.; Davies, D. L.; Rasheed, R. Ionic Liquids Based upon Metal Halide/Substituted Quaternary Ammonium Salt Mixtures. Inorg. Chem. 2004, 43, 3447-3452.

7 Carpio, R. A.; King, L. A.; Lindstrom, R. E.; Nardi, J. C.; Hussey, C. L. Density, Electric Conductivity, and Viscosity of Several N-Alkylpyridinium Halides and Their Mixtures with Aluminum Chloride. J. Electrochem. Soc. 1979, 126, 1644-1650.

8 Danford, J. J.; Arif, A. M.; Berreau, L. M. Poly[1-ethyl-3-methylimidazolium [tri- $\mu-$ chlorido-chromate(II)]]. Acta Cryst. Sect. E: Struct. Rep. Online. 2009, 65, m227.

9 Lee, C. K.; Peng, H. H.; Lin, I. J. B. Liquid Crystals of N,N'-Dialkylimidazolium Salts Comprising Palladium(II) and Copper(II) Ions. Chem. Mater. 2004, 16, 530-536.

10 Sun, H.; Harms, K.; Sundermeyer, J. The Crystal Structure of a Metal-containing Ionic Liquid: A New Octachlorotricuprate(II). Z. Kristallogr. 2005, 220, 42-44.

11 Zhong, C.; Sasaki, T.; Jimbo-Kobayashi, A.; Fujiwara, E.; Kobayashi, A.; Tada, M.; Iwasawa, Y. Syntheses, Structures, and Properties of a Series of Metal IonContaining Dialkylimidazolium Ionic Liquids. Bull. Chem. Soc. Jpn. 2007, 80, 23652374.

12 Sun, H.; Harms, K.; Sundermeyer, J. Aerobic Oxidation of 2,3,6-Trimethylphenol to Trimethyl-1,4-benzoquinone with Copper(II) Chloride as Catalyst in Ionic Liquid and Structure of the Active Species. J. Am. Chem. Soc. 2004, 126, 9550-9551. 
13 Hitchcock, P. B.; Seddon, K. R.; Welton, T. Hydrogen-bond Acceptor Abilities of Tetrachlorometalate(II) Complexes in Ionic Liquids. J. Chem. Soc. Dalton Trans. 1993, 2639-2643.

14 Takagi, Y.; Kusonoki, Y.; Yoshida, Y.; Tanaka, H.; Saito, G.; Katagiri, K.; Oshiki, T. Preparation of Magnetic Ionic Liquids Composed of Hybrid-Type Anions. Aust. J. Chem. 2012, 65, 1557-1560.

15 Yoshida, Y.; Otsuka, A.; Saito, G.; Natsume, S.; Nishibori, E.; Takata, M.; Sakata, M.; Takahashi, M.; Yoko, T. Conducting and Magnetic Properties of 1-Ethyl-3methylimidazolium (EMI) Salts Containing Paramagnetic Irons: Liquids $[\mathrm{EMI}]\left[\mathrm{M}^{\mathrm{III}} \mathrm{Cl}_{4}\right]\left(\mathrm{M}=\mathrm{Fe}\right.$ and $\left.\mathrm{Fe}_{0.5} \mathrm{Ga}_{0.5}\right)$ and Solid $[\mathrm{EMI}]_{2}\left[\mathrm{Fe}^{\mathrm{II}} \mathrm{Cl}_{4}\right]$. Bull. Chem. Soc. Jpn. 2005, 78, 1921-1928.

16 Bartlett, P. N.; Cummings, C. Y.; Leavson, W.; Pugh, D.; Reid, G. Halometallate Complexes of Germanium(II) and (IV): Probing the Role of Cation, Oxidation State and Halide on the Structural and Electrochemical Properties. Chem. Eur. J. 2014, 20, 5019-5027.

17 Mallick, B.; Metlen, A.; Nieuwenhuyzen, M.; Rogers, R. D.; Mudring, A. -V. Mercuric Ionic Liquids: $\left[\mathrm{C}_{n} \mathrm{mim}\right]\left[\mathrm{HgX}_{3}\right]$, Where $n=3,4$ and $\mathrm{X}=\mathrm{Cl}$, Br. Inorg. Chem. 2012, 51, 193-200.

18 Coleman, F.; Feng, G.; Murphy, R. W.; Nockemann, P.; Seddon, K. R.; SwadźbaKwaśny, M. Lead(II) Chloride Ionic Liquids and Organic/Inorganic Hybrid Materials-A Study of Chloroplumbate(II) Speciation. Dalton Trans. 2013, 42, 50255035.

19 Yang, S. -R.; Jiang, H. -F.; Li, Y. -Q.; Chen, H. -J.; Luo, W.; Xu, Y. -B. Protonolysis of the Carbon-palladium Bond in Palladium(II)-Catalyzed Enyne Cyclization in Imidazolium-type Ionic Liquids. Tetrahedron 2008, 64, 2930-2937.

20 Dullius, J. E. L.; Suarez, P. A. Z.; Einloft, S.; de Souza, R. F.; Dupont, J. Selective Catalytic Hydrodimerization of 1,3-Butadiene by Palladium Compounds Dissolved in Ionic Liquids. Organomet. 1998, 17, 815-819.

21 Ortwerth, M. F.; Wyzlic, M. J.; Baughman, R. G. Bis(1-ethyl-3-methylimidazolium) Tetrachloropalladate(II). Acta Cryst. Sect. C.: Cryst. Struct. Commun. 1998, 54, 1594-1596.

22 Currie, M.; Estager, J.; Licence, P.; Men, S.; Nockemann, P.; Seddon, K.R.; Swadźba-Kwaśny, M.; Terrade, C. Chlorostannate(II) Ionic Liquids: Speciation, Lewis Acidity, and Oxidative Stability. Inorg. Chem. 2013, 52, 1710-1721.

23 Estager, J.; Nockemann, P.; Seddon, K. R.; Swadźba-Kwaśny, M.; Tyrrell, S. Validation of Speciation Techniques: A Study of Chlorozincate(II) Ionic Liquids. Inorg. Chem. 2011, 50, 5258-5271.

24 Boon, J. A.; Carlin, R. T.; Elias, A. M.; Wilkes, J. S. Dialkylimidazolium-Sodium Chloroaluminate Ternary Salt System: Phase Diagram and Crystal Structure. J. Chem. Cryst. 1995, 25, 57-62.

25 Hasan, M.; Kozhevinov, I. V.; Siddiaui, M. R. H.; Steiner, A.; Winterton, N. N, $N^{6}-$ Dialkylimidazolium Chloroplatinate(II), Chloroplatinate(IV), and Chloroiridate(IV) Salts and an $N$-Heterocyclic Carbene Complex of Platinum(II): Synthesis in Ionic Liquids and Crystal Structures. Inorg. Chem. 2001, 40, 795-800. 
26 Serpell, C. J.; Cookson, J.; Thompson, A. L.; Brown, C. M.; Beer, P. D. Haloaurate and Halopalladate Imidazolium Salts: Structures, Properties, and Use as Precursors for Catalytic Metal Nanoparticles. Dalton Trans. 2013, 42, 1385-1393.

27 Williams, D. J.; Pennington, W. T.; VanDerveer, D.; Anderton, J. T.; White, K. M. The Preparation and Structural Characterization of 1-Methylimidazolium and 1,3Dimethylimidazolium Tetrachlorobismuthate (III). J. Chem. Cryst. 2003, 33, 465-472.

28 Pohako-Esko, K.; Wehner, T.; Schulz, P. S.; Heinemann, F. W.; Müller-Buschbaum, K.; Wasserscheid, P. Synthesis and Properties of Organic Hexahalocerate (III) Salts. Eur. J. Inorg. Chem. 2016, 1333-1339.

29 Champion, M. J. D.; Levason, W.; Pugh, D.; Reid, G. Hexahalometallate Salts of Trivalent Scandium, Yttrium, and Lanthanum: Cation-Anion Association in the Solid State and in Solution. New J. Chem. 2016, 40, 7181-7189.

30 Han, Y.; Lin, C.; Meng, Q.; Dai, F.; Sykes, A. G.; Berry, M. T.; May, P. S. $(\mathrm{BMI})_{3} \mathrm{LnCl}_{6}$ Crystals as Models for the Coordination Environment of $\mathrm{LnCl}^{3}(\mathrm{Ln}=$ $\mathrm{Sm}, \mathrm{Eu}, \mathrm{Dy}, \mathrm{Er}, \mathrm{Yb})$ in 1-Butyl-3-methylimidazolium Chloride Ionic-Liquid Solution. Inorg. Chem. 2014, 53, 5494-5501.

31 Hines, C. C.; Cocalia, V. A.; Rogers, R. D. Using Ionic Liquids to Trap Unique Coordination Environments: Polymorphic Solvates of $\mathrm{ErCl}_{3}\left(\mathrm{OH}_{2}\right)_{4} \cdot 2\left(\left[\mathrm{C}_{2} \mathrm{mim}\right] \mathrm{Cl}\right)$. Chem. Commun. 2008, 226-228.

32 Hines, C. C.; Cordes, D. B.; Griffin, S. T.; Watts, S. I.; Cocalia, V. A.; Rogers, R. D. Flexible Coordination Environments of Lanthanide Complexes Grown from Chloride-Based Ionic Liquids. New J. Chem. 2008, 32, 872-877.

33 Bäcker, T.; Breunig, O.; Valldor, M.; Merz, K.; Vasyleva, V.; Mudring, A. -V. InSitu Crystal Growth and Properties of the Magnetic Ionic Liquid $\left[\mathrm{C}_{2} \mathrm{mim}\right]\left[\mathrm{FeCl}_{4}\right]$. Cryst. Growth Des. 2011, 11, 2564-2571.

34 de Pedro, I.; Favelo, O.; García-Saiz, A.; Vallcorba, O.; Junquera, J.; Blanco, J. A.; Waerenborgh, J. C.; Wildes, D. A. A.; Fernández-Díaz, M. T.; Fernández, J. R. Dynamically Slow Solid-to-Solid Phase Transition Induced by Thermal Treatment of

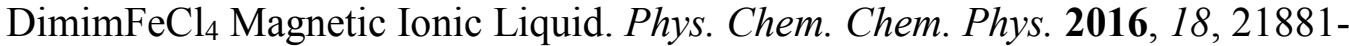
21892.

35 García-Saiz, A.; Migowski, P.; Vallcorba, O.; Junquera, J.; Blanco, J. A.; González, J. A.; Fernández-Díaz, M. T.; Rius, J.; Dupont, J.; Fernández, J. R.; de Pedro, I. A Magnetic Ionic Liquid Based on Tetrachloroferrate Exhibits Three-Dimensional Magnetic Ordering: A Combined Experimental and Theoretical Study of the Magnetic Interaction Mechanism. Chem. Eur. J. 2014, 20, 72-76.

36 Han, Y.; Dai, F.; Sykes, A. G.; May, S. P.; Berry, M. T.; Meng, Q.; Lin, C. catenaPoly[1-butyl-3-methylimidazolium [[dichlorido(methanol-кO)(propan-2-ol$\kappa O)$ lanthanate(III)]-di- $\mu$-chlorido]]. Acta Cryst. Sect. E: Struct. Rep. 2012, 68, m292$\mathrm{m} 293$.

37 Matsumoto, K.; Tusda, T.; Nohira, T.; Hagiwara, R.; Ito, Y.; Tamada, O. Tris(1ethyl-3-methylimidazolium) Hexachlorolanthanate. Acta Cryst. Sect C: Cryst. Struct. Commun. 2002, 58, m186-m187.

38 Wang, Z. -P.; Wang, J. -Y.; Li, J. -R.; Feng, M. -L.; Zou, G. -D.; Huang, X. -Y. [Bmim $]_{2} \mathrm{SbCl}_{5}$ : A Main Group Metal-Containing Ionic Liquid Exhibiting Tunable Photoluminescence and White-Light Emission. Chem. Commun. 2015, 51, 3094-3097. 
39 Dötterl, M.; Haas, I.; Alt, H. G. Solubility Behaviour of $\mathrm{TiCl}_{4}, \mathrm{ZrCl}_{4}$, and $\mathrm{HfCl}_{4}$ in Chloroaluminate Ionic Liquids. Z. Anorg. Allg. Chem. 2011, 637, 1502-1506.

40 Leye, J. -C.; Gijkaj, M.; Adam, A. Syntheses, Crystal Structures, Thermal Properties and Spectroscopic Characterization of Complex Chloridotitanates(IV) with Ionic Liquids. Eur. J. Inorg. Chem. 2009, 4838-4843.

41 Laus, G.; Bentivoglio, G.; Wurst, K.; Schottenberger, H.; Nauer, G. Crystal Structure of bis(1-butyl-3-methylimidazolium) Hexachlorotitanate(IV) bis(dichloromethane) Solvate, $\left(\mathrm{C}_{8} \mathrm{H}_{15} \mathrm{~N}_{2}\right)_{2}\left[\mathrm{TiCl}_{6}\right] \cdot 2 \mathrm{CH}_{2} \mathrm{Cl}_{2}$. Z. Kristallogr. 2005, 220, 577-578.

42 Nikitenko, S. I.; Hennig, C.; Grigoriev, M. S.; Le Naour, C.; Cannes, C.; Trubert, D.; Bossé, E.; Berthon, C.; Moisy, P. Structural and Spectroscopic Studies of the Complex $[\mathrm{BuMeIm}]_{2}\left[\mathrm{UCl}_{6}\right]$ in the Solid State and in Hydrophobic Room Temperature Ionic Liquid [BuMeIm][Tf 2 N]. Polyhedron 2007, 26, 3136-3142.

43 Hitchcock, P. B.; Lewis, R. J.; Welton, T. Vanadyl Complexes in AmbientTemperature Ionic Liquids. The First X-Ray Crystal Structure of a Tetrachlorooxovanadate(IV) Salt. Polyhedron 1993, 12, 2039-2044.

44 Runyan, C. E., Jr.; Hughbanks, T. Excising Hexanuclear Zirconium Clusters from Solids as a Route to Zirconium Cluster Solution Chemistry. J. Am. Chem. Soc. 1994, 116, 7909-7910.

45 Sun, D.; Hughbanks, T. Chloroaluminate Ionic Liquids as Reagents for Isolating Soluble Hexanuclear Zirconium Halide Cluster Compounds. Inorg. Chem. 2000, 39, 1964-1968.

46 Tian, Y.; Hughbanks, T. Extraction and Isolation of the $\left[\left(\mathrm{Zr}_{6} \mathrm{~B}\right) \mathrm{Cl}_{18}\right] 5-$ Cluster from a Solid State Precursor. Inorg. Chem. 1995, 34, 6250-6254.

47 Charushnikova, I.; Bossé, E.; Guillaumont, D.; Moisy, P. Crystal and Electronic Structure of a Mixed-Valent $\mathrm{Np}(\mathrm{IV})-\mathrm{Np}(\mathrm{V})$ Compound: [BuMeIm $]_{5}\left[\mathrm{~Np}\left(\mathrm{NpO}_{2}\right)_{3}\left(\mathrm{H}_{2} \mathrm{O}\right)_{6} \mathrm{Cl}_{12}\right]$. Inorg. Chem. 2010, 49, $2077-2082$.

48 Gjikaj, M.; Leye, J. -C.; Xie, T.; Brockner, W. Structural and Spectroscopic Elucidation of Imidazolium and Pyridinium Based Hexachloridophosphates and Niobates. CrystEngComm 2010, 12, 1474-1480.

49 König, J.; Dartsch, I.; Topp, A.; Guillamón, E.; Llusar, R.; Köckerling, M. Air-Stable, Well-Soluble $A_{2}^{\mathrm{I}}\left[\mathrm{Nb}_{6} \mathrm{Cl}_{18}\right]$ Cluster Compounds $\left(A^{\mathrm{I}}=\right.$ Organic Cation): A New Route for Preparation, Single-Crystal Structures, Properties, and ESI-Mass Spectra. $Z$. Anorg. Allg. Chem. 2016, 642, 572-578.

50 Qu, F.; Zhu, Q. -Q.; Liu, C. -L. Crystallization in Ionic Liquids: Synthesis, Properties, and Polymorphs of Uranyl Salts. Cryst. Growth Des. 2014, 14, 6421-6432.

51 Bäcker, J. Mihm, S.; Mallick, B.; Yang, M.; Meyer, G.; Mudring, A. -V. Crystalline and Liquid Crystalline Organic-Inorganic Hybrid Salts with Cation-Sensitized Hexanuclear Molybdenum Cluster Complex Anion Luminescence. Eur. J. Inorg. Chem. 2011, 4089-4095.

52 Freudenmann, D.; Feldmann, C. The Chloridomolybdenum(III) Cluster in $[\mathrm{BMIm}]_{4}\left[\mathrm{AgMo}_{10} \mathrm{Cl}_{35}\right]$ with Infinite Chains of $\mathrm{Ag}^{+}$-Linked $\left[\mathrm{Mo}_{10} \mathrm{Cl}_{35}\right]^{5-}$ Wheels. Dalton Trans. 2014, 43, 14109-14113.

53 Dijkgraaf, C. Charge-Transfer Complexes of Titanium Tetrachloride, Titanium Tetrabromide, and Vanadium Oxytrichloride with Aromatic Hydrocarbons. J. Phys. Chem. 1965, 69, 660-661. 
54 Sevast'yanova, T. N.; Suvorov, A. V. Thermochemical Parameters of Formation of Titanium Tetrachloride Adducts as a Measure of Donor-Acceptor Bond Strength. Russ. J. Coord. Chem. 1997, 23, 761-770.

55 Tolley, W. K.; Izatt, R. M.; Oscarson, J. L. Titanium Tetrachloride Supercritical Carbon-Dioxide Interaction: A Solvent-Extraction and Thermodynamic Study. Metallurg. Trans. B 1992, 23, 65-72.

56 Ehrlich, V. P.; Dietz, G. The Solvent Powder of Titanium Tetrachloride for Solid Chlorides. Z. Anorg. Allg. Chem. 1960, 305, 158-168.

57 Sibum, H.; Güther, V.; Roidl, O.; Habashi, F.; Wolf, H. U. Titanium, Titanium Alloys, and Titanium Compounds. Ullman's Encyclopedia of Industrial Chemistry; WileyVCH: Weinheim, 2012, vol. 37, pp. 51-82.

58 Gao, L.; Wang, L.; Qi, T.; Chu, J.; Qu, J. Preparation and Characterization of Titanium Tetrachloride-Based Ionic Liquids. J. Electrochem. Soc. 2009, 156, P49P55.

59 Dupont, J.; Consorti, C. S.; Suarez, P. A. Z.; de-Souza, R. F.; Fulmer, S. L.; Richardson, D. P.; Smith, T. E.; Wolff, S. Preparation of 1-Butyl-3-Methyl Imidazolium-Based Room Temperature Ionic Liquids. Org. Synth. 2002, 79, 236-243.

60 G. M. Sheldrick, Program for Semiempirical Absorption Correction of Area Detector Data, University of Göttingen, Germany, 1997.

61 Sheldrick, G. M. SHELXTL, Structure Determination Software Suite, v.6.10; 2001, Bruker AXS Inc.: Madison, WI.

62 Sheldrick, G. M. Crystal Structure Refinement with SHELXL. Acta Cryst. Sect. C.: Struct. Chem. 2015, 71, 3-8.

63 Abbott, A. P. Application of Hole Theory to the Viscosity of Ionic and Molecular Liquids. ChemPhysChem. 2004, 5, 1242-1246.

64 Cho, C.-W.; Pham, T. P. T.; Jeon, Y.-C.; Yun, Y.-S. Influence of Anions on the Toxic Effects of Ionic Liquids to a Phytoplankton Selenastrum Capricornutum. Green Chem. 2008, 10, 67-72.

65 Agustin, D.; Rima, G.; Gornitzka, H.; Barrau, J. Ligand Transfer Reactions between Schiff Base Divalent Group 14 Element Species and Titanium, Nickel, Boron, and Phosphorus Halides. Organometallics 2000, 19, 4276-4282.

66 Tian, C.; Nie, W.; Borzov, M. V.; Su, P. High-Yield Thermolytic Conversion of Imidazolium Salts into Arduengo Carbene Adducts with $\mathrm{BF}_{3}$ and $\mathrm{PF}_{5}$. Organometallics 2012, 31, 1751-1760.

67 Mathews, C. J.; Smith, P. J.; Welton, T. Palladium catalyzed Suzuki cross-coupling reactions in ambient temperature ionic liquids. Chem. Commun. 2000, 1249-1250.

68 Wang, X.; Vogel, C. S.; Heinemann, F. W.; Wasserscheid, P.; Meyer, K. Solid-State Structures of Double-Long-Chain Imidazolium Ionic Liquids: Influence of Anion Shape on Cation Geometry and Crystal Packing. Cryst. Growth Des. 2011, 11, 19741988.

69 Dieter, K. M.; Dymek, C. J., Jr.; Heimer, N. E.; Rovang, J. W.; Wilkes, J. S. Ionic Structure and Interactions in 1-Methyl-3-Ethylimidazolium Chloride-Aluminum Chloride Molten Salts. J. Am. Chem. Soc. 1988, 110, 2722-2726 
70 Zerkowski, J. A.; MacDonald, J. C.; Whitesides, G. M. Polymorphic Packing Arrangements in a Class of Engineered Organic Crystals. Chem. Mater. 1997, 9, 1933-1941.

71 Dieter, K. M.; Dymek, C. J., Jr.; Heimer, N. E.; Rovang, J. W.; Wilkes, J. S. Ionic Structure and Interactions in 1-Methyl-3-Ethylimidazolium Chloride-Aluminum Chloride Molten Salts. J. Am. Chem. Soc. 1988, 110, 2722-2726.

72 Decken, A.; Jenkins, H. D. B.; Knapp, C.; Nikiforov, G. B.; Passmore, J.; Rautiainen, J. M. The Autoionization of [ $\left.\mathrm{TiF}_{4}\right]$ by Cation Complexation with [15]Crown-5 To Give $\left[\mathrm{TiF}_{2}\left([15]\right.\right.$ crown-5)] $\left[\mathrm{Ti}_{4} \mathrm{~F}_{18}\right]$ Containing the Tetrahedral $\left[\mathrm{Ti}_{4} \mathrm{~F}_{18}\right]^{2-}$ Ion. Angew. Chem. Int. Ed. 2005, 44, 7958-7961.

73 Mazej, Z.; Goreshnik, E. Poly[perfluorotitanate(IV)] Salts of $\left[\mathrm{H}_{3} \mathrm{O}\right]^{+}, \mathrm{Cs}^{+},\left[\mathrm{Me}_{4} \mathrm{~N}\right]^{+}$, and $\left[\mathrm{Ph}_{4} \mathrm{P}\right]^{+}$and about the Existence of an Isolated $\left[\mathrm{Ti}_{2} \mathrm{~F}_{9}\right]^{-}$Anion in the Solid State. Inorg. Chem. 2009, 48, 6918-6923.

74 Jura, M.; Levason, W.; Petts, E.; Reid, G.; Webster, M.; Zhang, W. Taking TiF 4 Complexes to Extremes- The First Examples with Phosphine Co-Ligands. Dalton Trans. 2010, 39, 10264-10271.

75 The interactions are primarily hydrogen bonds between the imidazolium ring hydrogen atoms or hydrogen atoms on the methyl and ethylene groups $\alpha$ to the nitrogen atoms and the terminal $\mathrm{Cl}^{-}$ligands. Because of the geometry of the anion, the cations are able to simultaneously donate hydrogen bonds to a $\mathrm{Cl}^{-}$ligand while engaging in Coulombic stacking with other $\mathrm{Cl}^{-}$ligands on the same molecule.

76 Holbrey, J. D.; Reichert, W. M.; Nieuwenhuyzen, M.; Johnston, S.; Seddon, K. R.; Rogers, R. D. Crystal Polymorphism in 1-Butyl-3-Methylimidazolium Halides: Supporting Ionic Liquid Formation by Inhibition of Crystallization. Chem. Commun. 2003, 1636-1637.

77 Remya, P. N.; Reddy, M. L. Solvent Extraction Separation of Titanium(IV), Vanadium(V) and Iron(III) from Simulated Waste Chloride Liquors of Titanium Minerals Processing Industry by the Trialkylphosphine Oxide Cyanex 923. J. Chem. Technol. Biotechnol. 2004, 79, 734-741.

78 Zhou, Y.; Antonietti, M. Synthesis of Very Small TiO2 Nanocrystals in a RoomTemperature Ionic Liquid and Their Self-Assembly toward Mesoporous Spherical Aggregates. J. Am. Chem. Soc. 2003, 125, 14960-14961.

79 Ding, K.; Miao, Z.; Hu, B.; An, G.; Sun, Z.; Han, B.; Liu, Z. Study on the Anatase to Rutile Phase Transformation and Controlled Synthesis of Rutile Nanocrystals with the Assistance of Ionic Liquid. Langmuir 2010, 26, 10294-10302.

80 Endres, F.; El Abedin, S. Z.; Saad, A. Y.; Moustafa, E. M.; Borissenko, N.; Price, W. E.; Wallace, G. G.; MacFarlane, D. M.; Newman, P. J.; Bund, A. On the Electrodeposition of Titanium in Ionic Liquids. Phys. Chem. Chem. Phys. 2008, 10, 2189-2199.

81 Wilkes, J. S.; Frye, J. S.; Reynolds, G. F. Aluminum-27 and Carbon-13 NMR Studies of Aluminum Chloride-Dialkylimidazolium Chloride Molten Salts. Inorg. Chem. 1983, 22, 3870-3872.

82 Cousens, N. E. A.; Kearney, L. J. T.; Clough, M. T.; Lovelock, K. R. J.; Palgrave, R. G.; Perkin, S. Preparation and Characterization of High-Density Ionic Liquids Incorporating Halobismuthate Anions. Dalton Trans. 2014, 43, 10910-10919. 


\section{For Table of Contents Use Only}

Crystallographic Insights into the Behavior of Highly Acidic Metal Cations in Ionic Liquids from Reactions of Titanium Tetrachloride with [1-Butyl-3 Methylimidazolium][X] Ionic Liquids ( $X=$ Chloride, Bromide, Tetrafluoroborate)

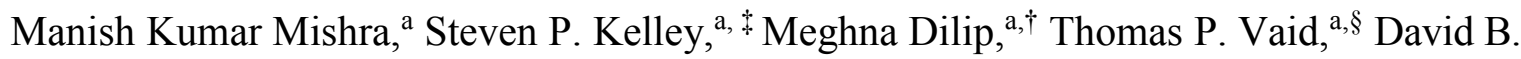

$$
\text { Cordes, }{ }^{a} \text { " } \text { Scott T. Griffin, }{ }^{a, \neq} \text { and Robin D. Rogers }{ }^{a, b, *}
$$

a Department of Chemistry, The University of Alabama, Tuscaloosa, AL 35487, USA

b525 Solutions, Inc., P.O. Box 2206, Tuscaloosa, AL 35403, USA

Present Address:

${ }^{\ddagger}$ S.P.K.: Department of Chemistry, University of Missouri, Columbia, MO 65211, USA

${ }^{\dagger}$ M.D.: Department of Chemistry, Worcester State University, Worcester, MA 01602, USA

$\S$ T.P.V.: Department of Chemistry, University of Michigan, Ann Arbor, MI 48109, USA

\# D.B.C.: School of Chemistry, University of St Andrews, St Andrews, KY16 9ST, UK

${ }^{¥}$ S. T. G.: Cytec Solvay Group, 1937 West Main St. Stamford, CT 06902, USA

\section{Corresponding Author}

*E-mail: rdrogers@ua.edu

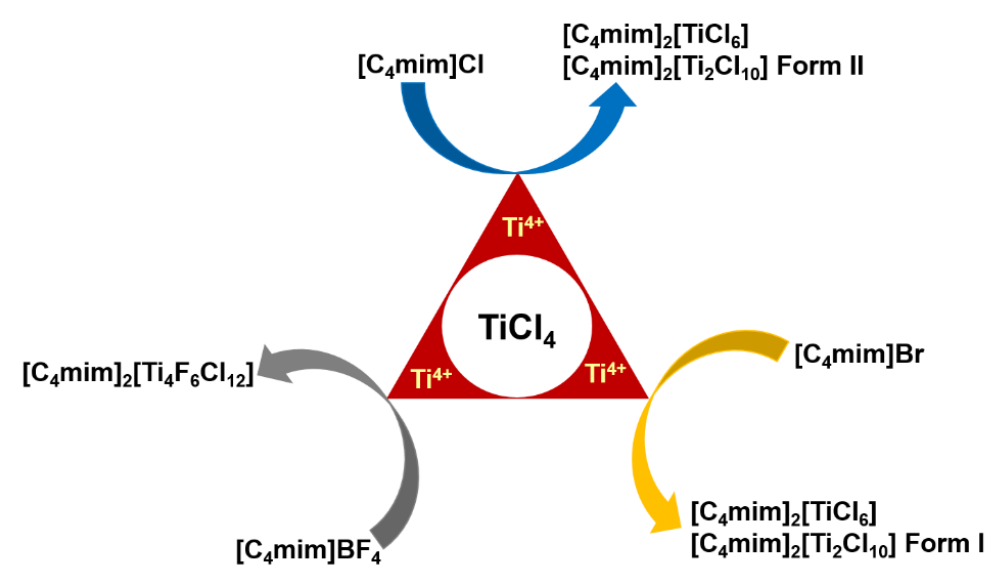

Synopsis: The crystallization of halotitanate complexes from reactions of $\mathrm{TiCl}_{4}$ with 1butyl-3-methylimidazolium $\left(\left[\mathrm{C}_{4} \mathrm{mim}\right]^{+}\right)$-based ionic liquids containing halides or tetrafluoroborate anions suggest the ability of $\mathrm{Ti}^{4+}$ to abstract bound fluoride and chloride from other components in the IL, even in the presence of excess bromide or 
tetrafluoroborate in the reaction mixture. This highlights the importance of Lewis acidity in maximizing the thermodynamically favored strong interactions. 